\title{
Ice Surface Velocity in the Eastern Arctic from Historical Satellite SAR Data
}

\author{
Tazio Strozzi ${ }^{1}$, Andreas Wiesmann ${ }^{1}$, Andreas Kääb ${ }^{2}$, Thomas Schellenberger ${ }^{2}$ and Frank Paul ${ }^{3}$ \\ ${ }^{1}$ Gamma Remote Sensing, 3073 Gümligen, Switzerland \\ $5 \quad{ }^{2}$ Department of Geosciences, University of Oslo, 0316 Oslo, Norway \\ ${ }^{3}$ Department of Geography, University of Zurich, 8057 Zürich, Switzerland
}

Correspondence to: Tazio Strozzi (strozzi@gamma-rs.ch)

\begin{abstract}
Knowledge on ice surface velocity of glaciers and ice caps contributes to a better understanding of a wide range of processes related to glacier dynamics, mass change and response to climate. Based on the recent release of historical SAR

10 data from various space agencies we compiled nearly complete mosaics of winter ice surface velocities for the 1990's over the Eastern Arctic (Novaya Zemlya, Franz-Josef-Land, Severnaya Zemlya and Svalbard), a region with sparse optical velocity records from these years. We mainly applied offset-tracking to JERS-1 SAR data and filled data gaps using SAR interferometry and offset-tracking from ERS-1/2 SAR data. We studied the long-term variability of winter ice surface velocity by comparing our 1990's results to 2008-2011 velocity maps from ALOS-1 PALSAR-1 and 2020-2021 maps from

15 Sentinel-1. A general increase of winter velocities from the 1990's to present along with a retreat of glacier fronts is obsverved. Exceptions to this general pattern are surges, which are widespread over Svalbard but rarely found in the other three regions. The dense time series of ice surface velocity from Sentinel-1 since 2015 were also considered to infer the representativeness of winter data with respect to mean annual values. We found that for non-surging glaciers short-term seasonal fluctuations are relatively small and winter ice surface velocities are a good representative of mean annual

20 velocities with an underestimation of less than $10 \%$. Together with consistent datasets of glacier ice thickness and terminus position, the ice surface velocities in the Eastern Arctic provide the basis to quantify the regional decadal average calving flux during the 1990's. The ice surface velocity data set for the 1990's over the Eastern Arctic from satellite SAR data can be downloaded from https://doi.pangaea.de/10.1594/PANGAEA.938381 (Strozzi et al., 2021).
\end{abstract}

\section{Introduction}

25 Glaciers and ice caps are retreating and thinning nearly everywhere in the world. Mass loss in recent decades was ascertained in various studies from a range of techniques and sensors, including glaciological observations (Zemp et al., 2019), satellite gravimetry observations (Wouters et al., 2019), differencing surface elevations from satellite and airborne observations (Hugonnet et al., 2021), and analysis of satellite interferometric altimetry (Tepes et al., 2021). In order to understand the mechanisms behind glacier mass loss and the discrepancies between the various studies, it is worthy to investigate the 30 contributions of various components of mass loss. The calving flux of a glacier can be determined by multiplying its flow 
https://doi.org/10.5194/essd-2022-44

Preprint. Discussion started: 17 February 2022

(c) Author(s) 2022. CC BY 4.0 License.

(c) (i)

velocity with its cross section at its grounding line (Paterson, 1994), so that for calving glaciers variations in flow velocities are directly related to the ice mass flux. Spatially and temporally consistent datasets of surface velocity are thus required to obtain the dynamic discharge component of mass loss from calving glaciers. An assessment of long-term trends and of seasonal variations would improve the related estimates. In addition, knowledge on ice surface velocity of glaciers and ice caps contributes to a better understanding of a wide range of glacial dynamics processes, for example flow modes and flow instabilities (e.g. surges), subglacial processes (e.g. erosion), supra- and intra-glacial mass transport, the development of glacier lakes and associated hazards, and improved estimates of ice thickness distribution. Satellite observations offer an appealing opportunity to reconstruct the evolution of glacier velocities back in time. Available ice surface velocity products such as GoLive (Global Land Ice Velocity Extraction from Landsat 8, Scambos et al., 2016), ITS-live (The Inter-mission

40 Time Series of Land Ice Velocity and Elevation, Gardner et al., 2018) and the FAU-Glacier Portal (Global time series and temporal mosaics of glacier surface velocities derived from Sentinel-1 data of the Friedrich-Alexander-University ErlangenNürnberg, Friedl et al., 2021) have almost global coverage for the years since 2014 but not from before. In particular, data gaps exist for the Eastern Arctic from the 1990-2000 period due to the lack of good quality data from past Landsat missions.

45 The archives of past SAR sensors such as ERS-1/2 (1991-2010) and JERS-1 (1992-1998) are now freely and openly available. We exploit this opportunity to create datasets of ice surface velocity for the Eastern Arctic estimated for the 1990's using offset-tracking and SAR Interferometry (InSAR). The number of image pairs with suitable information available from these sensors, however, is limited in space and time, because these past sensors had irregular acquisition strategies and the orbital configurations put important constraints on obtaining good quality results. Hence, to retrieve spatially and temporally

50 consistent datasets, regional velocity mosaics have to be created by compiling results from the best winter scene-pairs over several years. In this contribution, such nearly complete mosaics of ice surface velocities were computed for the 1990's for Novaya Zemlya, Franz-Josef-Land, Severnaya Zemlya and Svalbard.

We first describe the methods used to compute the ice surface velocity maps and give specific detailed description of the 55 data products. In the following, we discuss long-term changes of winter ice surface velocities in the Eastern Arctic by comparing the 1990's mosaics to Sentinel-1 results of the winter 2020/2021. Where available, previously published velocity data derived from winter ALOS-1 PALSAR-1 data between 2008 and 2011 (Strozzi et al., 2017) are also included in our discussion about the spatial extent and magnitude of changes to highlight the temporal consistency of the trends or consider possible accelerating trends. Because glacier motion undergoes strong temporal variability, in particular on the seasonal time 60 scale, one might ask in how far the mosaics, computed from SAR data over short time-intervals (typically 1 to 44 days) for several winter seasons in the 1990's, are representative of annual average results. To investigate this issue, we computed for a large number of glaciers dense time series of ice surface velocity from Sentinel-1 since 2015 and analysed short-term fluctuations in comparison to their annual means. 


\section{Methods}

65

Features that move on the surface of a glacier (e.g., crevasses, debris, radar speckle, etc.) can be tracked between two satellite images acquired at different times to measure ice surface displacement. The development of feature tracking algorithms based on intensity cross-correlation procedures is well established in glaciological studies and led to an automation of image processing with a related increase in efficiency and accuracy (Burgess et al., 2013; Paul et al., 2015;

70 Dehecq et al., 2015; Nagler et al., 2015; Fahnestock et al., 2016; Strozzi et al., 2017). We employed the offset-tracking algorithm of the Gamma software (Strozzi et al., 2002; Werner et al., 2005) and considered the following data:

$\rightarrow$ JERS-1 SAR data available from ESA (European Space Agency) as Single Look Complex (SLC) images (Level 1) and from JAXA (Japan Aerospace Exploration Agency) as RAW images (Level 0);

$\rightarrow$ ERS-1/2 SAR data available from ESA as RAW images (Level 0);

$75 \rightarrow$ ALOS-1 PALSAR-1 Fine Beam Single (FBS) data available from JAXA, ESA and ASF (Alaska Satellite Facility) as RAW images (Level 0);

$\rightarrow$ IW (Interferometric Wide) Swath Sentinel-1 SAR data from Copernicus available as SLC (Level 1).

Image pairs were analysed for the same tracks and frames (Paul et al., 2015; Strozzi et al., 2017). Our main pre-processing

80 steps included downloading of the data, optional focusing of RAW data to SLC images for Level 0 data, optional burst mosaic creation for Sentinel-1 data, and quality control. The main processing steps included geocoding of the reference image, co-registration of the slave image to the geometry of the master scene and offset-tracking via normalized intensity cross-correlation with the variable processing parameters listed in Table 1. In addition, multi-looked products such as differential interferograms and backscattering intensity and coherence images were computed. Digital Elevation Models

85 (DEM) were used for the geocoding of the satellite SAR data, in order to derive three-dimensional ice surface displacement maps combining the slant-range and azimuth offsets by assuming that flow occurs parallel to the ice surface, and for differential interferometry. Over Svalbard, Novaya Zemlya and Franz-Josef-Land we used the TanDEM-X Intermediate DEM (IDEM) for that purpose, while for Severnaya Zemlya we used the digital elevation data derived from Soviet Union topographic maps of 1:100,000 and 1:200,000 scale as compiled by ViewfinderPanoramas (http://viewfinderpanoramas.org;

90 last access: 6 September 2021). Both datasets are provided in 3 arcsec resolution and geographic coordinates (Strozzi et al., 2017). The main post-processing steps included filtering of noise, mitigation of ionospheric azimuth streaks based on highpass filtering along the range direction (Wegmüller et al., 2006), geocoding, computation of statistical measures over ice-free regions, and final velocity product creation. 
95 The archive of JERS-1 data at ESA was systematically mined and all image pairs in series from the same track and frame were analysed. Only results obtained for 44-day winter image pairs were further considered, because in summer and over longer time periods the ice surface velocity maps contained much noise and reduced spatial coverage. Where no 44-day winter JERS-1 image pairs were found in the ESA archive, the JERS-1 data archive at JAXA was searched to complement the results. Further data gaps existed for the far east of Franz-Josef-Land, entire Severnaya Zemlya and the central part of

100 Svalbard. In these regions we tracked ERS-1 data with time intervals of 9 to 18 days.

Table 1. Processing parameters for different sensors.

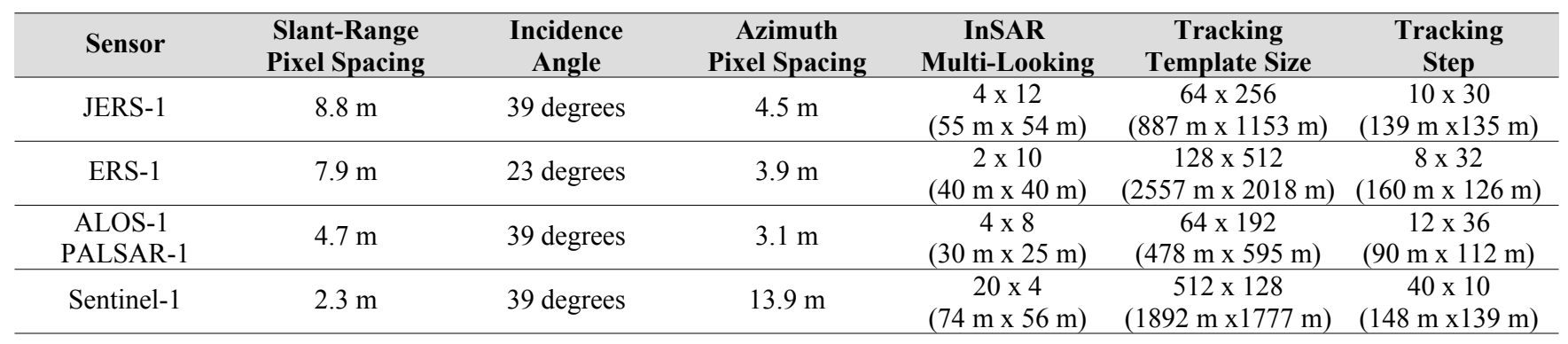

\subsection{SAR interferometry}

105 The use of differential SAR interferometry to map surface displacements at centimetre-resolution is well established in research and operational projects (Luckman et al, 2002; Dowdeswell et al., 2008; McMillan et al., 2014). The interferometric phase is sensitive to both surface topography and coherent displacement along the look vector occurring between the two acquisitions of the interferometric image pair. The differential use of a high-resolution DEM (2-pass InSAR) or of two SAR image pairs acquired within short time periods (3/4-pass InSAR) allow the removal of the topographic phase from the

110 interferogram to derive a displacement map. In the case of 2-pass InSAR, the acquisition date of the DEM has to match that of the SAR dataset close enough to ensure that no major topographic signal is left on the differential interferograms. In the case of 3/4-pass InSAR, displacement within the two image pairs is assumed constant. In addition, short perpendicular baselines of the SAR image pairs are preferred, in order to minimize the effect of the residual topographic phase so that phase signals can be interpreted as ice surface displacement in the satellite line-of-sight direction, with possible atmospheric

115 disturbances.

ERS-1/2 InSAR results from previous studies (Dowdeswell et al., 2008; Nuth et al., 2019) were considered to improve the quality and completeness of the results over Nordaustlandet, south Spitsbergen and north-west Spitsbergen (Svalbard). The ERS-1/2 InSAR ice velocity map of Nordaustlandet combines interferometric phases from 1-day ERS-1/2 image pairs and is produced for the winter 1995/1996 at 100 m resolution. Method and uncertainties are described in Dowdeswell et al. (2008).

120 In most cases errors are assumed to be smaller than $7 \mathrm{~m} / \mathrm{a}$, while for unfavourable combinations of image pairs this value is slightly larger. The ERS-1/2 InSAR ice velocity map of south Spitsbergen is produced from winter 1996 and 1997 data at 20 
https://doi.org/10.5194/essd-2022-44

Preprint. Discussion started: 17 February 2022

(c) Author(s) 2022. CC BY 4.0 License.

\section{(c) (1)}

$\mathrm{m}$ resolution. Method and uncertainties are described in Nuth et al. (2019). The accuracy was measured by extracting displacements across a point grid of $1000 \mathrm{~m}$ spacing excluding points which were not on stable terrain (glaciers, fjords, etc.). Nuth et al. (2019) found a median value of $2.3 \mathrm{~m} / \mathrm{a}$ and a standard deviation of $2.6 \mathrm{~m} / \mathrm{a}$. The same processing and accuracy

125 assessment procedure was also applied to 1-day ERS-1/2 image pairs of winter 1995/1996 over north-west Spitsbergen . In this case, a median value of $4.0 \mathrm{~m} / \mathrm{a}$ and a standard deviation of $3.7 \mathrm{~m} / \mathrm{a}$ were found.

\section{Data}

Two sets of data containing ice surface velocities over the Eastern Arctic can be downloaded from https://doi.pangaea.de/10.1594/PANGAEA.938381. The first set of data contains the velocities derived from offset-tracking 130 of all image tracks from this study as original research data in vector format with metadata information. Nine collections of data wrapped up in single files for easy storage (tar packaging followed by a gzip compression) are available: the JERS-1 (1992-1998) results over Novaya Zemlya, Franz-Josef-Land, and Svalbard, the ERS-1 (1991-1992) results over Franz-JosefLand, Severnaya Zemlya and Svalbard and the ALOS-1 PALSAR-1 (2006-2011) results over Novaya Zemlya, Franz-JosefLand, and Svalbard. A comma-separated values file (.csv) provides the northing and easting coordinates of measurement 135 points, the elevation from the above-mentioned DEMs, the displacement in metres in the $\mathrm{x}, \mathrm{y}$ and $\mathrm{z}$ directions and the crosscorrelation coefficient for each measurement. A metadata file in extensible markup language format (.xml) provides information about the SAR images (<inputSatelliteData1> and <inputSatelliteData2 $>$ ), the processing parameters ( $<$ processingParameters $>$ ) and quality aspects of the data such as the percent of valid information over ice ( $<$ QA-IV-2 $>$ ) and statistical measures over ice-free regions ( $<$ QA-IV-3 $>$ ). In addition, the original research data packages include for each image pair GeoTIFF files of the three-dimensional ice surface displacement maps (.tif in single-precision floating-point format and .300.tif as exemplary display of the colour-coded displacement map with saturation at $300 \mathrm{~m} / \mathrm{a}$ ), the two intensity images (.pwr1.tif and .pwr2.tif), the differential interferogram (.tflt.tif), the phase coherence image (.cc.tif), an RGB colour composite of the coherence, intensity and intensity difference between both images (.rgb.tif), and the layover and shadow map (.ls_map.tif. In all cases data are provided the Universal Transverse Mercator (UTM) projection (zones 33N for Svalbard, 40N for Novaya Zemlya and Franz-Josef Land, and 47N for Severnaya Zemlya) with a spatial resolution of $100 \mathrm{~m}$.

The second set of data contains velocity mosaics of the best JERS-1 results over Novaya Zemlya, Franz-Josef-Land, and Svalbard, the best ERS-1 results over Franz-Josef-Land, Severnaya Zemlya and Svalbard and the best ALOS-1 PALSAR-1 results over Novaya Zemlya, Franz-Josef-Land, and Svalbard in GeoTIFF format. In addition, we provide in the same format also the winter ERS-1/2 InSAR ice velocity map, used to improve the quality of the results over Svalbard, and Sentinel-1 mosaics computed from winter 2020/2021 data, considered in the following section to study the long-term variability of winter ice surface velocity over the Eastern Arctic. Appendix A provides the lists of the satellite data considered over the four study regions along with some technical information and Figure 1 shows the SAR footprints. 


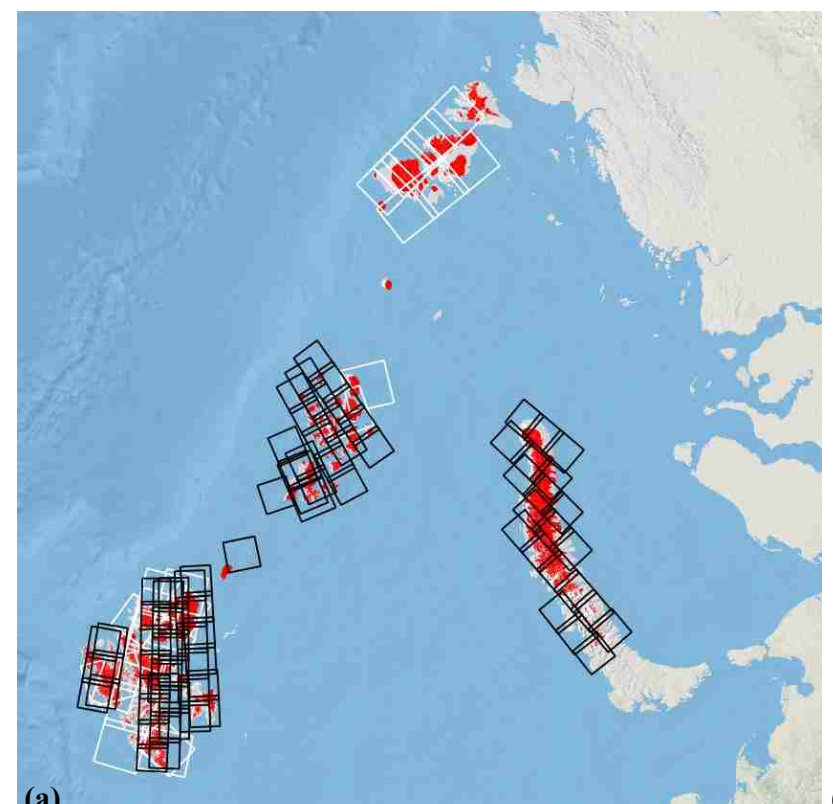

(a)

Figure 1: a) JERS-1 (black) and ERS-1 (white) SAR footprints. b)

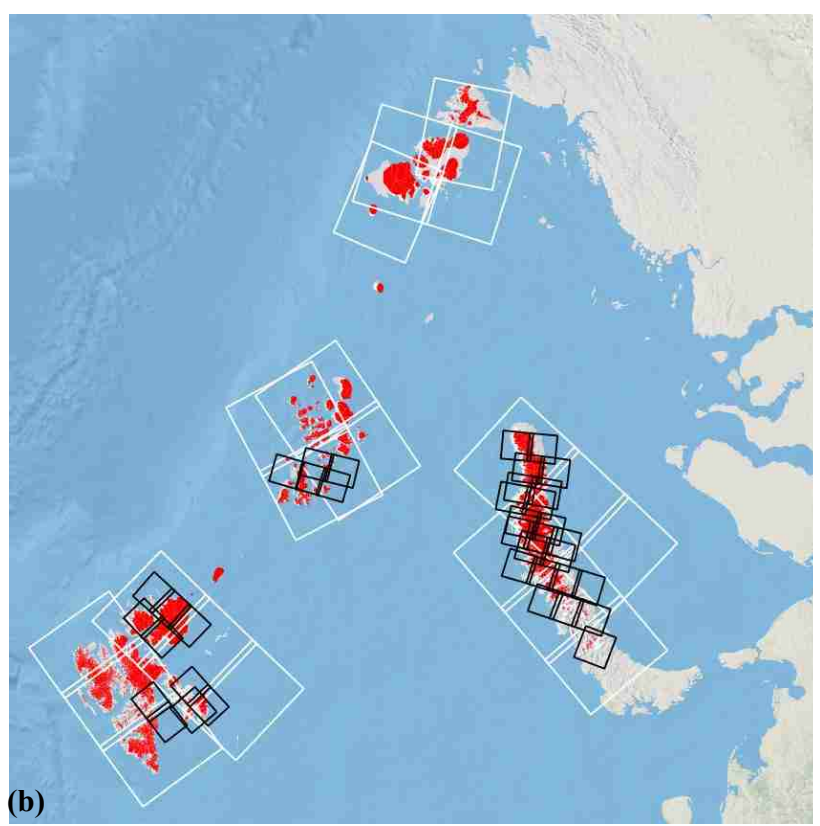

b) ALOS-1 (black) and Sentinel-1 (white) SAR footprints.

\section{Results}

\subsection{Flow velocities for distinct periods}

Mosaics of ice velocity maps of the 1990's for Novaya Zemlya, Franz-Josef-Land, Severnaya Zemlya and Svalbard are presented in Figures 2a, 4a, 5a, and 6a, respectively. In the Russian High Arctic, priority in the winter ice velocity mosaics was given to JERS-1 offset-tracking over ERS-1 offset-tracking. Glaciers were masked out from land and sea using glacier outlines from satellite imagery acquired between 2000 and 2010 during summer (Moholdt et al., 2012), after manual adjustment using the SAR backscattering intensity images of the front position of the glaciers that significantly retreated or advanced from the 1990's to the 2000's. In addition, for Severnaya Zemlya we included ice flow over the Matusevich Ice Shelf that collapsed in 2012 (Willis et al., 2015). Over Svalbard, priority in the winter ice velocity mosaic was given to ERS1/2 InSAR over JERS-1 offset-tracking, with ERS-1 offset-tracking considered to fill minor data gaps over north-east Spitsbergen. Over this region we considered the glacier outlines from summer satellite imagery spanning the period 20002010 (Nuth et al., 2013) after correction from the SAR backscattering intensity images for the front position of the major retreating or advancing glaciers. 
https://doi.org/10.5194/essd-2022-44

Preprint. Discussion started: 17 February 2022

(c) Author(s) 2022. CC BY 4.0 License.

Sentinel-1 mosaics computed from winter 2020/2021 data that showed the best spatial coverage are considered to study the long-term variability of winter ice surface velocity. The four Sentinel-1 velocity maps for Novaya Zemlya, Franz-JosefLand, Severnaya Zemlya and Svalbard are shown in Figures 2c, 4b, 5b and 6b, respectively. Glaciers were masked out from land and sea using satellite imagery acquired between 2013 and 2016 over Novaya Zemlya (Rastner et al., 2017), in 2016 for

175 Franz-Josef-Land (unpublished), between 2000 and 2010 over Severnaya Zemlya (Moholdt et al., 2012) with additional manual adjustment of the surge over the Vavilov Ice Cap, and between 2016 and 2018 for Svalbard (unpublished). Difference maps between the 1990's and 2020/2021 velocity data were computed for all study regions only where the 2020/2021 Sentinel-1 ice velocities are larger than 50 m/a. Figures 3c, 4c, 5c and 6c show the difference maps for Novaya Zemlya, Franz-Josef-Land, Severnaya Zemlya and Svalbard, respectively. Only areas within the newest glacier inventories 180 for Novaya Zemlya (Rastner et al., 2017), Franz-Josef-Land (unpublished) and Svalbard (unpublished) and the Randolph Glacier Inventory (RGI) 6.0 for Severnaya Zemlya (Moholdt et al., 2012) are included.

Where available, we include in our discussion previously published velocity results from ALOS-1 PALSAR-1 (Strozzi et al., 2017) in order to highlight the temporal consistency of the changes or point to possible trends and differences. In particular,

185 we consider a nearly complete mosaic computed for Novaya Zemlya from winter ALOS-1 PALSAR-1 data acquired between 2008 and 2010. This mosaic is shown in Figure 2b with glaciers masked out from land and sea using glacier outlines from satellite imagery acquired between 2000 and 2010 during summer (Moholdt et al., 2012). The difference maps between the 1990's and 2000's velocity maps and between the 2000's and 2020/2021 velocity maps for Novaya Zemlya are shown in Figures $3 \mathrm{a}$ and $3 \mathrm{~b}$, respectively. For the other regions, only very limited scattered results are available from ALOS1 PALSAR-1 between 2008 and 2011, which are discussed in Section 4.2.

\subsection{Long-term variability of ice surface velocity}

\subsubsection{Novaya Zemlya}

Over the western coast of Novaya Zemlya along the Barents Sea coast, where marine-terminating glaciers have the highest

195 frontal velocities of the archipelago (Figure 2), we observe an increase in frontal velocities from 1998 to 2021 for all the 18 major outlet glaciers with Sentinel-1 winter 2021 velocities larger than $100 \mathrm{~m} / \mathrm{a}$ (Figure 3c). In most of the cases, the increase of frontal velocities exceeds $100 \mathrm{~m} / \mathrm{a}$ and is spread over a large frontal part of the outlet glaciers. In only a few cases frontal velocities in 1998 and 2021 were similar, but the retreat of the glacier front since 1998 and a larger area with fast velocity in 2021 resulted in a strong signal in Figure 3c. Over the eastern coast of Novaya Zemlya we observe an increase of

200 frontal velocity of more than $100 \mathrm{~m} / \mathrm{a}$ from 1998 to 2021 over 8 of the $>15$ major outlet glaciers. The spatial extent of the frontal velocity increase is more limited across the eastern coast than the western coast. For all the 26 outlet glaciers with significant velocity changes, the front retreated from 1998 to 2021. The analysis of the ALOS-1 SAR data of 2008-2010 shows that the general increase of frontal velocities along with a retreat of frontal positions over Novaya Zemlya is 
https://doi.org/10.5194/essd-2022-44

Preprint. Discussion started: 17 February 2022

(c) Author(s) 2022. CC BY 4.0 License.

\section{(c) (1)}

particularly evident in recent years (Figure 3b), indicating an enhanced trend of velocity increase in more recent periods. The general pattern of ice velocity changes between 1998 and 2008-2010 is more contrasted (Figure 3a), with at least five glaciers along the western coast of Novaya Zemlya showing a decrease in frontal velocities. Apart from Severny Island 1 Glacier, we did not detect any sign of destabilisation for the glaciers on Novaya Zemlya. In this region the inter-annual changes of winter ice surface velocity between 1998 and 2021 exceed seasonal variability (Figure 11) and can be considered a significant representation of the long-term variability of ice surface velocity over this region.

\subsubsection{Franz-Josef-Land}

Over Franz-Josef-Land, the general pattern of the differences between winter ice surface velocities from the 1990's to 2020/2021 is dominated by glaciers with an increase in frontal velocities in recent years (Figure 4c). We observe, however, also at least three glaciers with a clear (i.e., $<-50 \mathrm{~m} / \mathrm{a}$ ) decrease of frontal speeds. Glacier fronts generally retreated from the

215 1990's to 2020/2021, with two exceptions. Simony Glacier on McClintock Island advanced by about 800 m from 1998 to 2021 and probably underwent a frontal destabilisation in the early 2010's (Strozzi et. al. 2017). The most west-oriented glacier of the Tyndal Ice Cap on Hall Island advanced by nearly 500 m from 2017 to 2019 to reach in 2021 approximately the same position as in 1998. ALOS-1 PALSAR-1 winter image pairs were acquired only over the western part of FranzJosef-Land in 2010-2011 (Figure 1b). Already between 1996-1998 and 2010-2011 (Figure 7a) we observe a general increase of ice velocity, which continued for many (but not all) glaciers between 2010-2011 and 2021 (Figure 7b) so that the general patterns of changes from the 1990's to 2021 are dominated by glaciers with an increase in frontal velocities (Figure 7c). Over Franz-Josef-Land, we did not detect any clear sign of destabilisation and the inter-annual changes of winter ice surface velocity, which exceed seasonal variability, can be considered representative of the long-term variability of ice surface velocity.

\subsubsection{Severnaya Zemlya}

Changes in the ice surface velocity observed between the 1990's and 2020/2021 over Severnaya Zemlya (Figure 5c) are more prominent than over Novaya Zemlya (Figure 3c) and Franz-Josef-Land (Figure 4c). While there are larger errors from the ERS-1 data (Figure 5a) available for this region than for JERS-1 data for Novaya Zemlya and Franz-Josef-Land (Figures

$2302 \mathrm{a}$ and $4 \mathrm{a}$ ), these results have better spatial coverage than those available from previous studies with winter ERS-1/2 InSAR data (Dowdeswell et al., 2002) and summer ALOS-1 PALSAR-1 data (Strozzi et al., 2017). Over the Academy of Sciences Ice Cap, we observe a widespread increase of ice surface velocities from 1991 to 2020/2021 of more than $100 \mathrm{~m} / \mathrm{a}$ for five large and two small glaciers. For two glaciers over this ice cap, the maximum speeds at the front were actually higher in 1991 than in 2020/2021. This is not reflected in Figure 5c, however, due to the retreat of the glaciers. Over the Vavilov Ice 235 Cap, we observe a widespread increase of ice surface velocities from 1991 to 2020/2021, where a surge possibly followed by the transition to an ice stream is occurring since 2015 (Glazovsky et al., 2015; Willis et al., 2018; Zheng et al., 2019). It is worth mentioning that the ERS-1 records indicate stagnant ice over large parts of the Vavilov Ice Cap in 1991. Other smaller 
https://doi.org/10.5194/essd-2022-44

Preprint. Discussion started: 17 February 2022

(c) Author(s) 2022. CC BY 4.0 License.

regions with an increase of speed are recorded over the Rusanov Ice Cap (four glaciers) and Karpinsky Ice Cap (two). To the north of the Karpinsky Ice Cap, one glacier had significantly larger velocities in 1991 compared to 2020/2021, which is visible by blue colours in Figure 5c. Prior to the collapse of the Matusevich Ice Shelf in 2012 (Willis et al., 2015), this glacier largely extended across the sea between the Karpinsky and Rusanov Ice Caps. Over Severnaya Zemlya, we again observe a general retreat of frontal positions from 1991 to 2020/2021. The only two exceptions are the surging outlet glacier of the Vavilov Ice Cap and one glacier flowing towards south over the Academy of Sciences Ice Cap with stagnant ice in 1991 (Figure 5a) and a high velocity in 2020/2021 (Figure 5b). Over Severnaya Zemlya there were unfortunately no suitable winter ALOS-1 PALSAR-1 acquisitions to compute ice surface velocities over 46 days at the end of the 2000's. Over Severnaya Zemlya, we detected two glaciers with clear signs of destabilisation. Also for these, however, the inter-annual changes of winter ice surface velocity, which exceed seasonal variability, again represent the long-term variability of ice surface velocity rather well.

\subsubsection{Svalbard}

The difference map between ice surface velocities in the 1990's and 2021 for areas with Sentinel-1 velocities larger than 50 $\mathrm{m} / \mathrm{a}$ over Svalbard (Figure 6c) shows a large increase of velocities for many glaciers. Along with glaciers having significantly higher frontal velocities (e.g., Monacobreen, Kronebreen and Osbornbreen on Spitsbergen and Schweigaardbreen, Leighbreen, and Basin 7 on Austfonna), there are also many prominent surges, e.g., Basin 3 (Austfonna), Stonebreen (Edgeyoa), Negribreen and Sonklarbreen (Spitsbergen) and a few other smaller ones. Over south Spitsbergen we observe the only glacier with significantly higher velocities in the 1990's, Mendelejevbreen, which surged apprixmately in 2000 (Blaszczyk et al., 2009). Other large glaciers that were surging during the 1990's, such as Monacobreen in 1994 (Luckman et al., 2002) and Fridtjovbreen in 1996 (Murray et al., 2003), are not captured in our mosaic shown in Figure 6a, because the data were from either after (1998 in the case of Monacobreen) or before (1992 in the case of Fridtjovbreen) the peak of the surges. Additionally, also for other large glaciers that surged between the 1990's and 2021, such as Tunabreen in 2004 (Flink et al., 2015), Nathorsbreen in 2009 (Sund et al., 2014; Nuth et al., 2019), Basin 2 in 2015 (Schellenberger et al., 2017) and Strongbreen in 2016 (Benn et al., 2019), there are no signals visible in Figure 6c. The signals of the surges of Strongbreen and Basin 2, however, are captured well in Sentinel-1 images of the years prior to 2021, when flow over these two glaciers became stagnant after the surge (Friedl et al., 2021). The overview of frontal position changes between the 265 1990's and 2021 over Svalbard has more contrasts than over the other three study regions. Again, we observe a general retreat of frontal positions, but there are also strong advances for recently surging glaciers (e.g., Negribreen, Sonklarbreen, Nathorstbreen, Strongbreen, Basin 3 and Basin 2). Other glaciers such as Basin 7 and Stonebreen have nearly the same position in 2021 as in the 1990's, with a retreat from 1990's to 2015 compensated by a recent advance. Tunabreen is also nearly at the same frontal position in 2021 as in the 1990's, by reason of a surge in 2004 and a further surge-like advance in 270 2017/2018. The front of Fridtjovbreen, which surged in 1996, is still more advanced in 2021 than in 1991. ALOS-1 PALSAR-1 winter image pairs were acquired only over the eastern part of Svalbard in 2008-2011 (Figure 1b). Already 
https://doi.org/10.5194/essd-2022-44

Preprint. Discussion started: 17 February 2022

(c) Author(s) 2022. CC BY 4.0 License.

(c) (i)

between the 1990's and 2008 (Figure 8a), we observe a general increase of ice velocity over Nordaustlandet, which continued for nearly all glaciers until 2021 (Figure 8b). A slight decrease of ice velocity between 2008 and 2021, however, is visible over Duvebreen and Franklinbreen, which both underwent an active surge initiated in winter 1998/99 (Pohjola et al.,

2011). A strong increase of ice velocity between 2011 and 2021 is observed in Figure 8b also over Stonebreen (Edgeyoa), while the surges of Negribreen and Sonklarbreen are not visible in Figure 8b, because they are not covered by ALOS-1 PALSAR-1. Due to the colour saturation at $100 \mathrm{~m} / \mathrm{a}$, the very strong increase of velocities over Basin 3 is actually underlined in Figures $8 \mathrm{~b}$ and $8 \mathrm{c}$. The long-term variability of ice surface velocity from a mosaic computed over short-time intervals from several years is much less representative of yearly averages over Svalbard than over the three other study regions, even without taking into account that over this region a large number of glaciers (more than ten according to Leclercq et al. (2021)) underwent surging events in recent years.

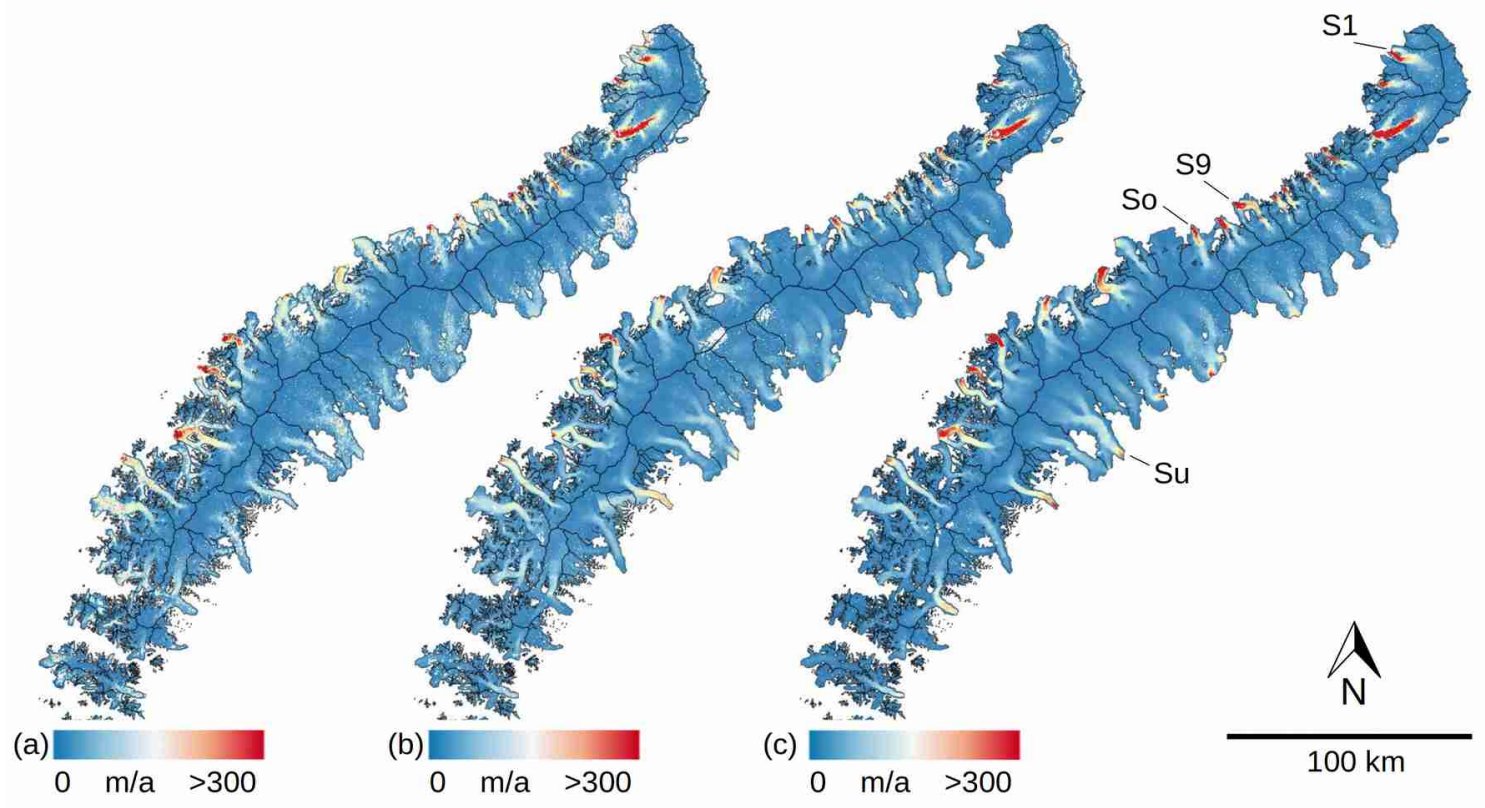

Figure 2: Ice velocity maps for Novaya Zemlya: (a) JERS-1 1998.01.21-1998.03.25, (b) ALOS-1 2008.12.11-2010.04.29, (c) Sentinel- 
https://doi.org/10.5194/essd-2022-44

Preprint. Discussion started: 17 February 2022

(c) Author(s) 2022. CC BY 4.0 License.

(c) (i)

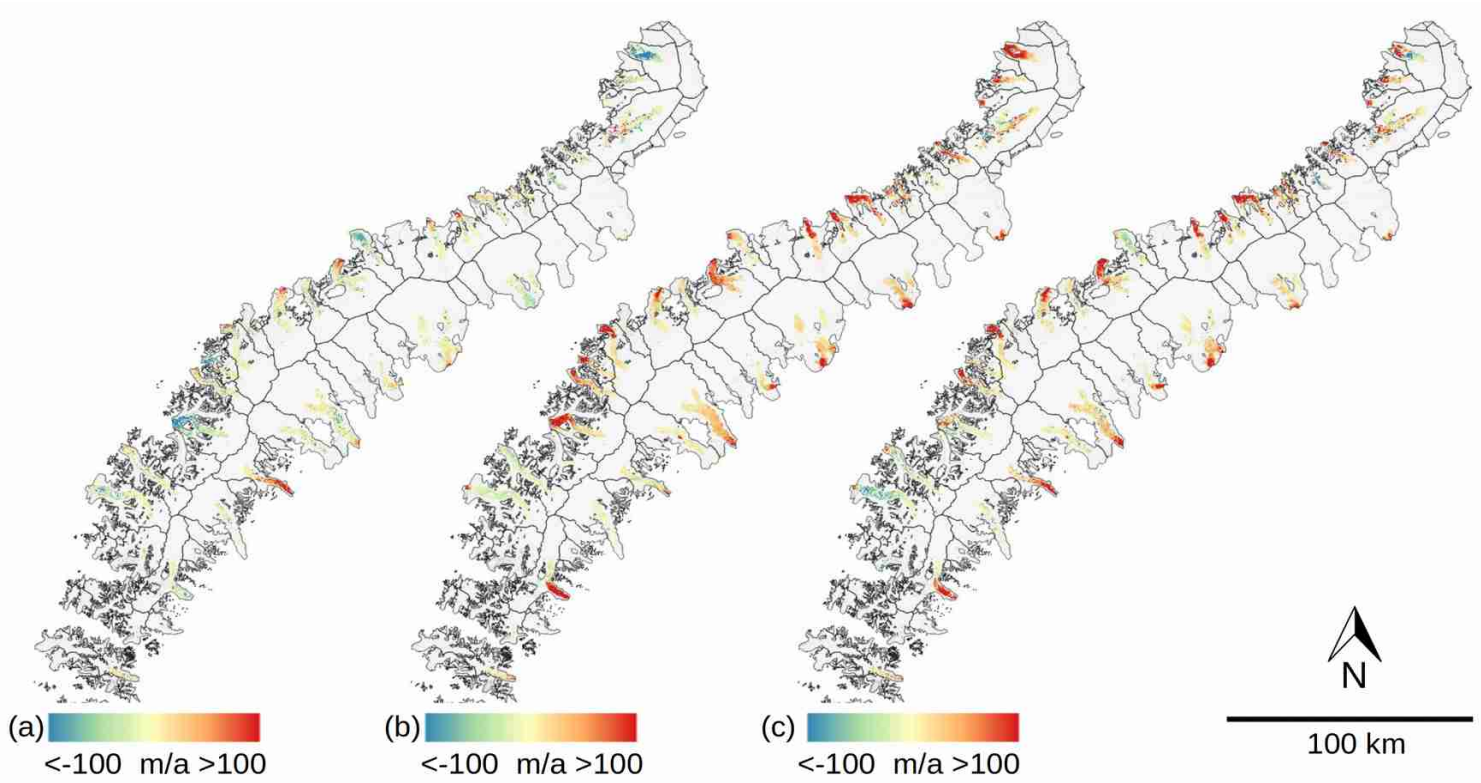

Figure 3: Difference maps for areas with Sentinel-1 2021 velocity larger than $50 \mathrm{~m} / \mathrm{a}$ for Novaya Zemlya: (a) ALOS-1 - JERS-1, (b) Sentinel-1 - ALOS-1, (c) Sentinel-1 - JERS-1. Glacier outlines from Rastner et al. (2017). JERS-1 data were acquired in 1998,

ALOS-1 PALSAR-1 in 2008-2011 and Sentinel-1 in 2021.

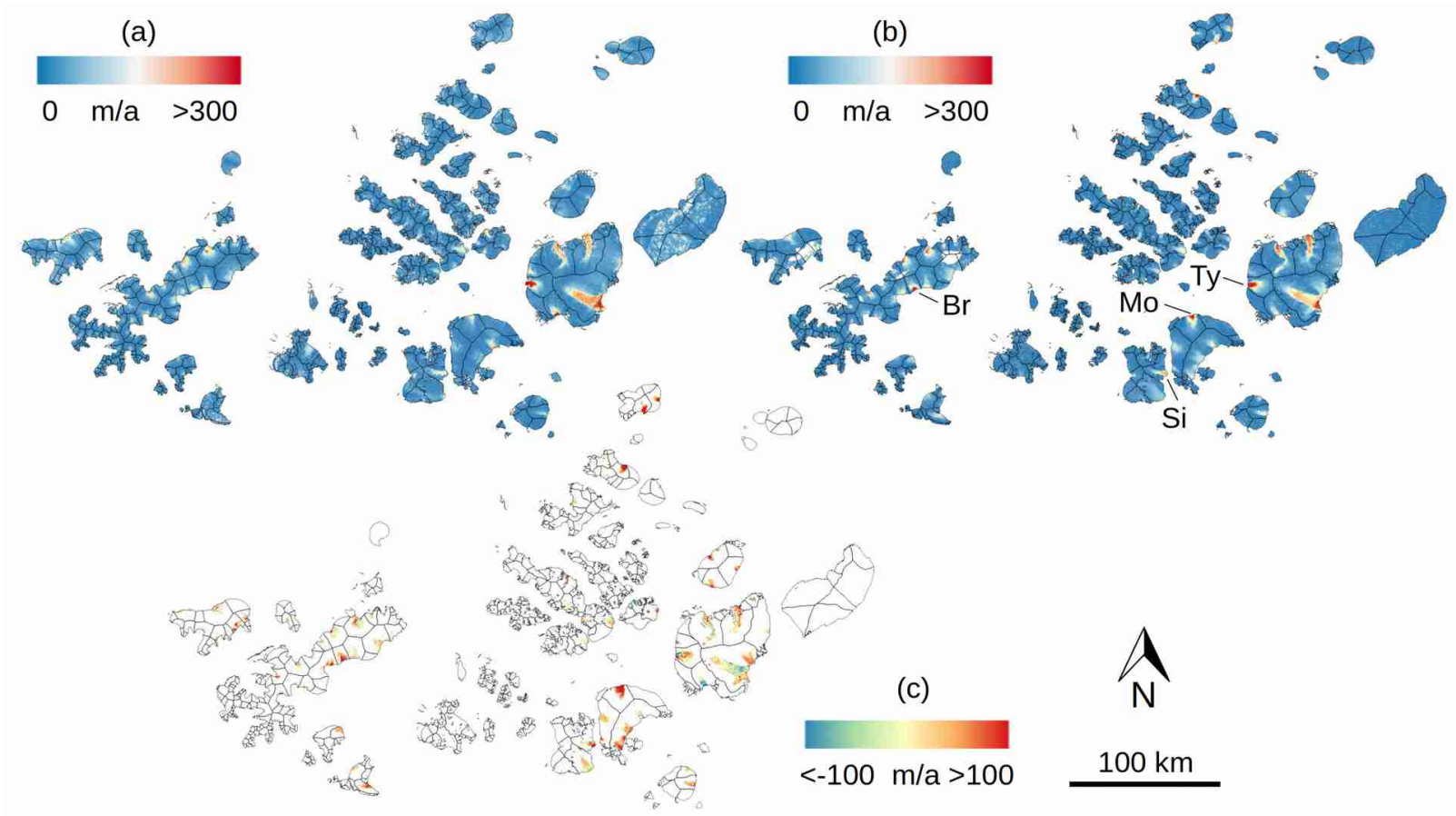

Figure 4: Ice velocity maps for Franz-Josef-Land: (a) JERS1 1996.04.04-1998.05.29 \& ERS1 1991.10.12-1991.11.17, (b) Sentinel-1 2021.01.10-2021.02.12. (c) Difference map for areas with Sentinel-1 velocity $>50 \mathrm{~m} / \mathrm{a}$. Glacier outlines from 2016 (unpublished). Letters refer to glaciers (Si: Simony) and ice caps (Ty: Tyndal; Mo: Moscow; Br: Brousilov) mentioned in the text. 
https://doi.org/10.5194/essd-2022-44

Preprint. Discussion started: 17 February 2022

(c) Author(s) 2022. CC BY 4.0 License.

(c)
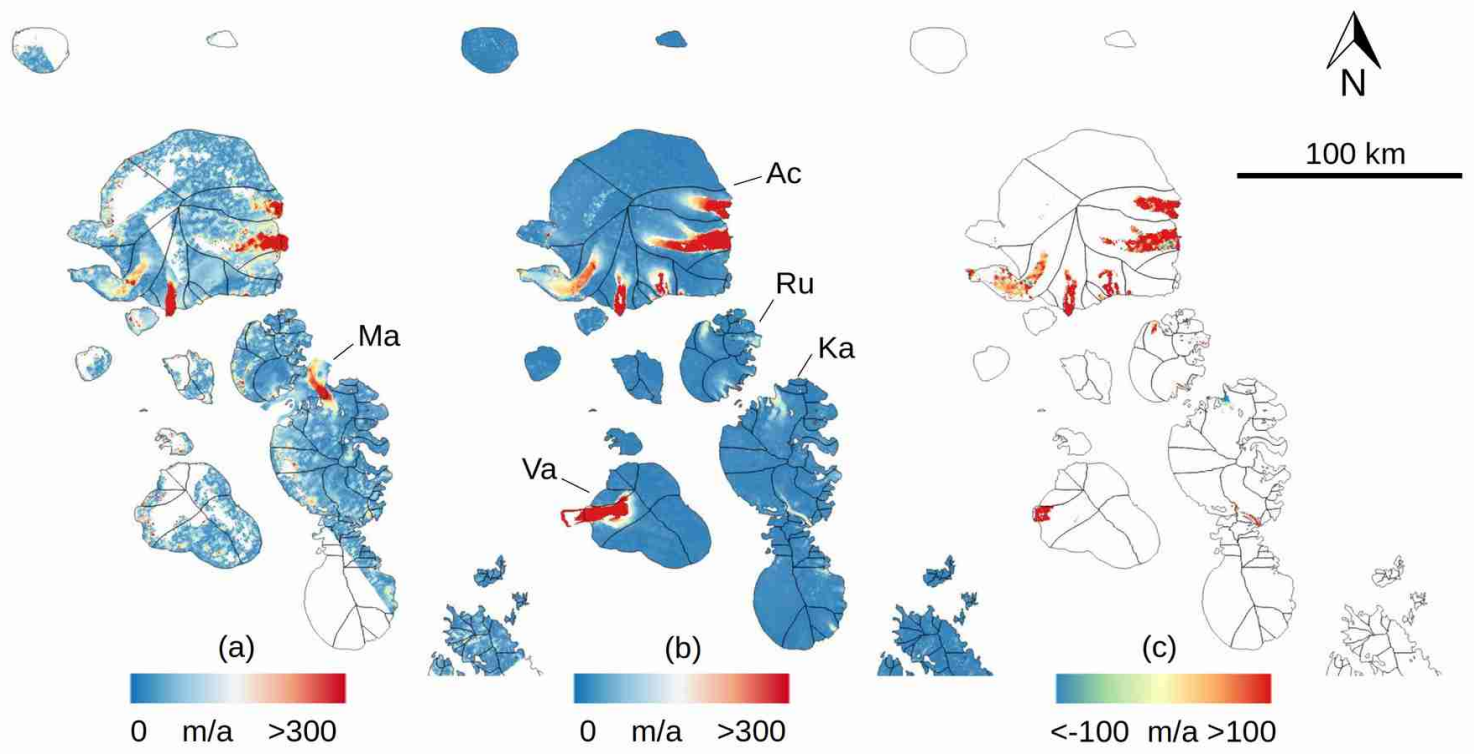

Figure 5: Ice velocity maps for Severnaya Zemlya: (a) ERS1 1991.10.18-1992.03.02, (b) Sentinel-1 2020.12.15-2021.02.25. (c) Difference map for areas with Sentinel-1 velocity $>50 \mathrm{~m} / \mathbf{a}$. Glacier outlines from RGI 6.0 (Moholdt et al., 2012). Letters refer to the Matusevich Ice Shelf (Ma) and ice caps mentioned in the text (Ac: Academy of Sciences; Va: Vavilov; Ka: Karpinsky; Ru: Rusanov).
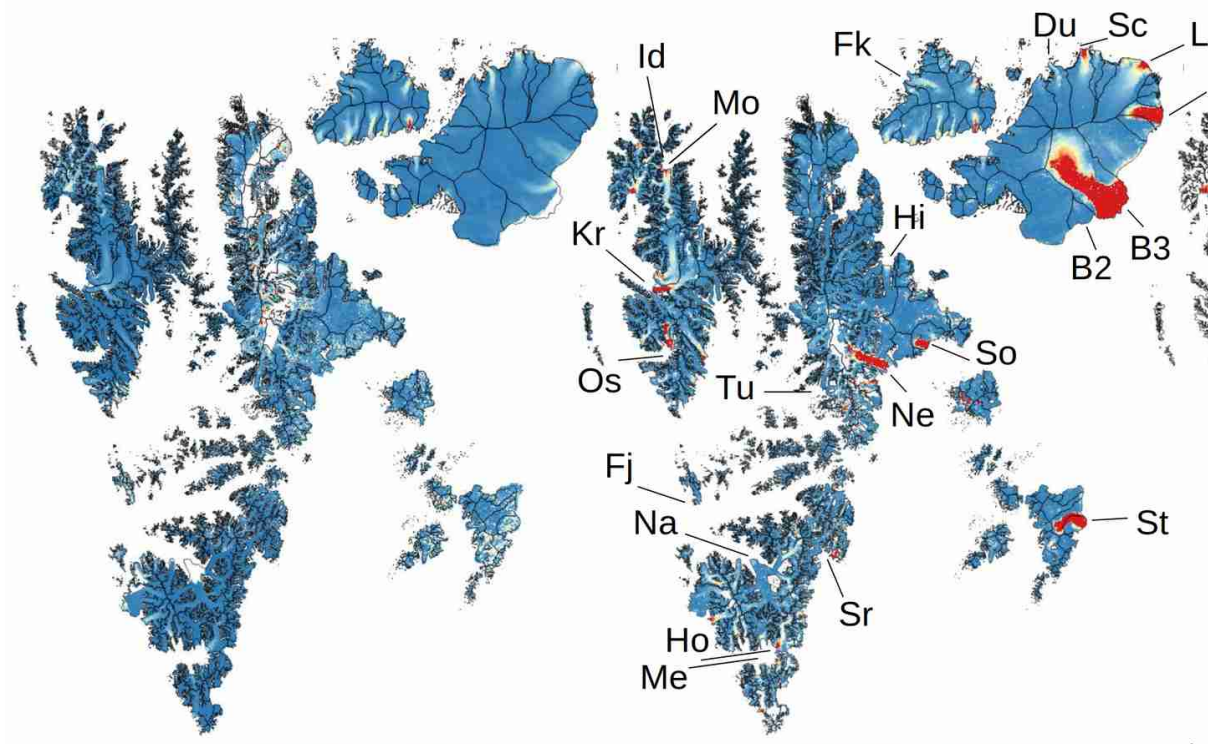

(a)

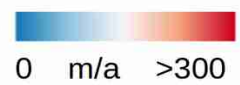

$100 \mathrm{~km}$ (b)

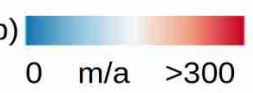

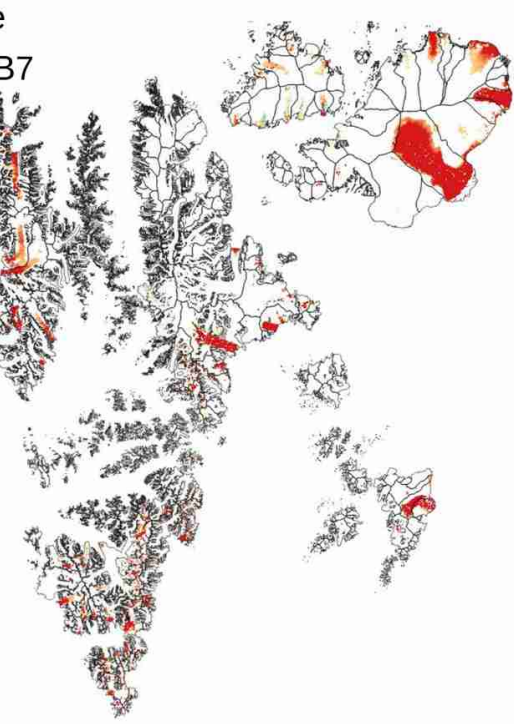

$\mathrm{A}_{\mathrm{N}}$ (c) $<-100 \mathrm{~m} / \mathrm{a}>100$

Figure 6: Ice velocity maps for Svalbard: (a) ERS-1/2 1995.12.10-1995.01.29 \& JERS1 1994.02.05-1998.03.26 \& ERS-1 1992.01.031992.01.15 and (b) Sentinel-1 2021.01.26-2021.02.12. (c) Difference map for areas with Sentinel-1 velocity $>50$ m/a. Glacier outlines between 2016 and 2018 (unpublished). Letters refer to glaciers mentioned in the text (Mo: Monacobreen; Id: Idabreen; Kr: Kronebreen; Os: Osbornbreen; Hi: Hinlopenbreen; Tu: Tunabreen; Ne: Negribreen; So: Sonklarbreen; Fj: Fridtjovbreen; Na: 
https://doi.org/10.5194/essd-2022-44

Preprint. Discussion started: 17 February 2022

(c) Author(s) 2022. CC BY 4.0 License.

(c) (i)

Nathorsbreen; Sr: Strongbreen; Ho: Hornbreen; Me: Mendelejevbreen; Fk: Franklinbreen; Du: Duvebreen; Sc: Schweigaardbreen; Le: Leighbreen; B2: Basin 2; B3: Basin 3; B7: Basin 7; St: Stonebreen).

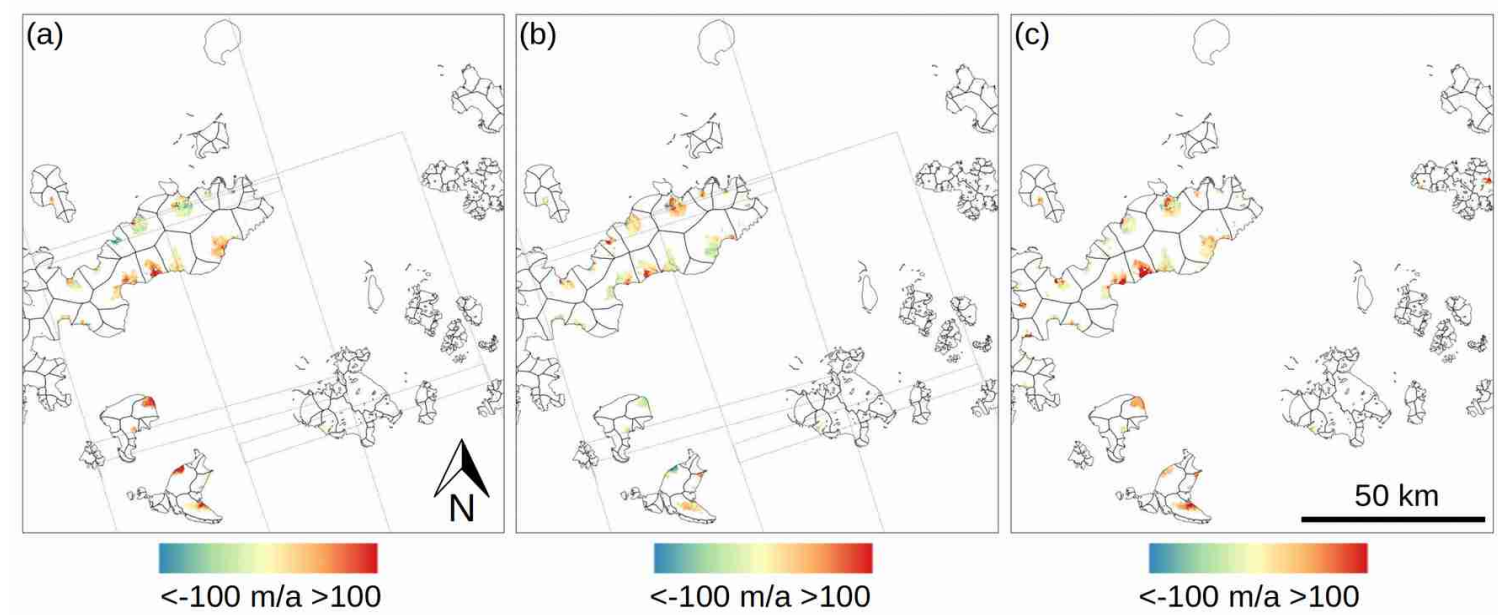

Figure 7: Difference maps for areas with Sentinel-1 2021 velocity larger than 50 m/a for western Franz-Josef-Land: (a) ALOS-1 JERS-1, (b) Sentinel-1 - ALOS-1, (c) Sentinel-1 - JERS-1. Glacier outlines from 2016 (unpublished). ALOS-1 SAR footprints are shown in (a) and (b). JERS-1 data were acquired in 1991-1998, ALOS-1 PALSAR-1 in 2010-2011 and Sentinel-1 in 2021.
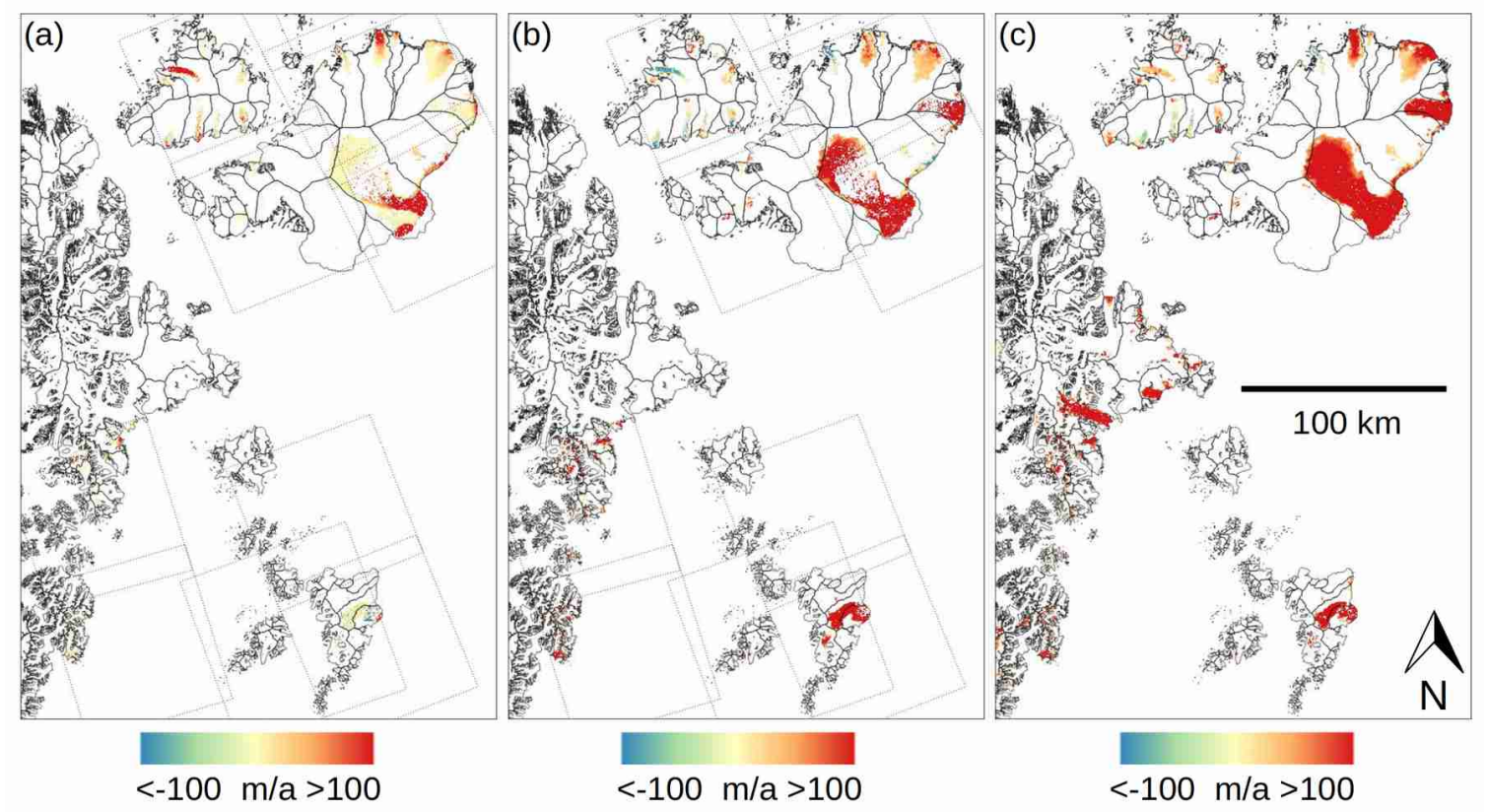

Figure 8: Difference maps for areas with Sentinel-1 2021 velocity larger than 50 m/a for eastern Svalbard: (a) ALOS-1 - JERS-1, (b) Sentinel-1 - ALOS-1, (c) Sentinel-1 - JERS-1. Glacier outlines between 2016 and 2018 (unpublished). ALOS-1 SAR footprints are shown in (a) and (b). JERS-1 data were acquired in 1992-1998, ALOS-1 PALSAR-1 in 2008-2011 and Sentinel-1 in 2021. 


\section{Discussion}

\subsection{Error sources: product quality and seasonal variability of ice surface velocity}

Uncertainties in winter ice surface velocity estimations originate from errors in tracking offsets between image pairs as well as unknown representativeness of winter velocity mosaics with regard to the annual average velocities. Paul et al. (2017) extensively discussed the factors influencing the product quality and described various measures to determine precision and accuracy. External factors influencing product quality include glacier surface conditions, structure and terrain complexity and ionospheric scintillations. Internal factors influencing product quality include the choice of the matching window size and oversampling factor and the post-processing to filter the noise of the resulting estimates. Validation of glacier displacements measured from spaceborne sensors compared to ground-based data is inherently difficult, because it requires temporally consistent in-situ and satellite observations of similar spatial scale and displacement direction. Therefore, uncertainties in velocity-based products are frequently characterized based on internal measures. Here, we do not reiterate the numerous internal measures that exist to validate the data, but make reference to previous work. In particular, according to previous studies, our SAR-derived velocities have uncertainties of $\pm 20 \mathrm{~m} / \mathrm{a}$ for JERS-1 (Strozzi et al., 2008), $\pm 40 \mathrm{~m} / \mathrm{a}$ for ERS-1 (Dowdeswell et al., 2008), \pm 10 m/a for ALOS-1 PALSAR-1 (Paul et al., 2015) and $\pm 20 \mathrm{~m} / \mathrm{a}$ for Sentinel-1 (Strozzi et al., 2017). More specific quality aspects, such as a comment from an experienced operator based on visual inspection of the resulting displacements ( $<$ QA-IV-1 $>$, if applicable), the percent of valid information over ice $(<\mathrm{QA}-\mathrm{IV}-2>$ ) and statistical measures over ice-free regions $(<\mathrm{QA}-\mathrm{IV}-3>$ ), are given in the metadata information of each dataset (.xml). These quality aspects are listed in Appendix A for the data considered in the velocitiy mosaics. The characterisation of the matching quality of individual ice velocity estimates is also given by the cross-correlation coefficient given in the comma-separated values file (.csv).

In order to infer in how far the mosaics computed from SAR data over short time-intervals (typically 1 to 44 days) for several winter seasons in the 1990's are representative of annual average results, we analyse short-term variability in glacier flow from Sentinel-1 data regularly available since 2015 with 12-day repetition rate. While ice velocity maps derived for winter with Sentinel-1 have an excellent coverage of valid information over both the interior of the ice caps and the outlet glaciers, summer results are often limited to the crevassed outlet glaciers, because surface melt strongly alters the appearance of other surface features in SAR intensity images. For a large number of glaciers showing Sentinel-1 winter velocities larger than $100 \mathrm{~m} / \mathrm{a}$, we selected one representative point close to each glacier front and extracted time series of velocities computed every 12 days. Examples of time series for glaciers over Novaya Zemlya, Franz-Josef-Land, Severnaya Zemlya and Svalbard with distinctly different patterns are shown in Figures 9 to 12. In addition, we computed an annual average ice surface velocity and compared it to winter (October-May) and summer (June-September) averages. A linear trend was not subtracted from this comparison, although there are some signs of changes. Figure 13 graphically summarises the percentage 
https://doi.org/10.5194/essd-2022-44

Preprint. Discussion started: 17 February 2022

(c) Author(s) 2022. CC BY 4.0 License.

(c) (i)

differences between winter and summer velocities compared to annual averages for the selected glaciers over the four study regions. Appendix B lists the statistics for all the glaciers analysed in our study. The time series of ice surface velocities for the 26 glaciers analysed in our study on Novaya Zemlya, the 27 glaciers analysed over Franz-Josef-Land, the 17 glaciers analysed over Severnaya Zemlya, and the 30 glaciers analysed over Svalbard, all with Sentinel-1 velocities larger than 100 $\mathrm{m} / \mathrm{a}$, are shown in Appendix C.

\subsubsection{Novaya Zemlya}

The time series of every glacier display characteristic patterns, with possible year-to-year (e.g., accelerations, decelerations, pulses, destabilisations or surges) and seasonal (e.g., summer speed-up events, generally higher summer or winter velocities) changes. Shury Glacier on Novaya Zemlya (Figure 9a) is, for instance, characterised by short-term, strong summer accelerations. Shokalskiy Glacier (Figure 9b) generally flows faster in winter than in summer, but also has summer accelerations. Severny Island 1 Glacier (Figure 9c) shows an increase in velocity from 2017 to 2021 with higher summer values. The front of this glacier also advanced by more than $300 \mathrm{~m}$ from 2015 to 2021 . For the 26 glaciers on Novaya Zemlya with Sentinel-1 velocities larger than $100 \mathrm{~m} / \mathrm{a}$, the velocities in the winter period differed between $-12 \%$ and $+4 \%$ (average -3\%) from the average annual velocities. For the summer period, the related differences were between $+33 \%$ and $12 \%$ (average $+8 \%$ ). Summer differences are larger than those in winter, because the summer speed-ups are short, intensive events and the summer period is shorter.
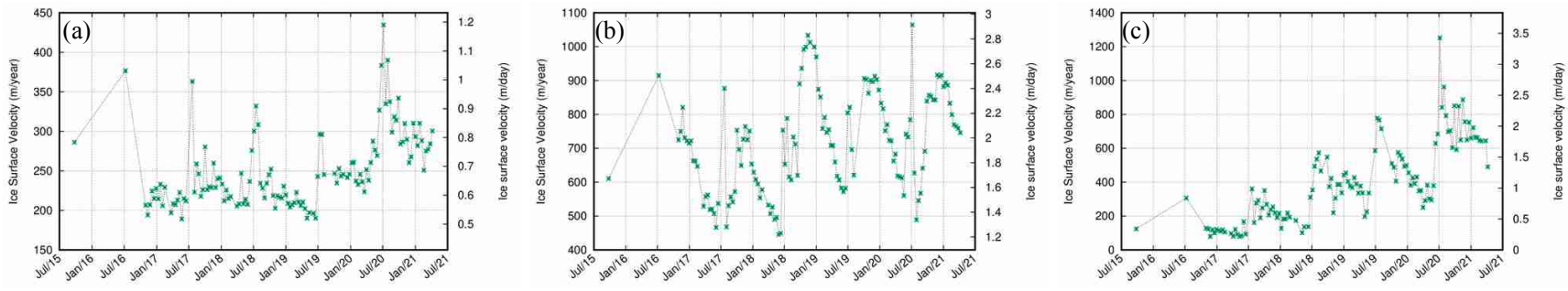

Figure 9: Novaya Zemlya: time series of Sentinel-1 velocity for (a) Shury Glacier (mean 250 m/a, mean summer 280 m/a (+11.8\%), mean winter 238 m/a (-4.8\%)), (b) Shokalskiy Glacier (mean 719 m/a, mean summer 671 m/a (-6.8\%), mean winter $737 \mathrm{~m} / \mathrm{a}(+2.5 \%)$ ) and (c) Severny Island 1 (mean 396 m/a, mean summer $507 \mathrm{~m} / \mathrm{a}(+27.9 \%)$, mean winter $356 \mathrm{~m} / \mathrm{a}(-10.2 \%))$.

\subsubsection{Franz-Josef-Land}

Over Franz-Josef-Land the Sentinel-1 acquisitions stopped in 2018-2019 and the time series of Figure 10 are incomplete and more difficult to interpret. Simony Glacier on McClintock Island (Figure 10a), which advanced by about $800 \mathrm{~m}$ from 1998 to 2021 and underwent a frontal destabilisation in the early 2010's (Strozzi et al., 2017), shows generally decreasing velocities from 2015 to 2021 with strong summer speed-up events. The west-oriented glacier of the Tyndal Ice Cap on Hall Island (Figure 10b), which advanced by nearly $500 \mathrm{~m}$ from 2017 to 2019, had similar velocities in 2017/2018 and 2020 and lower 
https://doi.org/10.5194/essd-2022-44

Preprint. Discussion started: 17 February 2022

(c) Author(s) 2022. CC BY 4.0 License.

(c) (1)

ones in 2021, but the most interesting period in 2018-2019 is missing. A glacier on Moscow Ice Cap shows strong summer speed-up events followed by slowly decreasing values (Figure 10c). For the 27 glaciers analysed over Franz-Josef-Land with Sentinel-1 velocities larger than $100 \mathrm{~m} / \mathrm{a}$, the velocities in the winter period differed between $-11 \%$ and $+3 \%$ (average $-3 \%$ ) from the average annual velocities. In the warm period, they differed between $+43 \%$ and $-11 \%$ (average $+12 \%$ ).
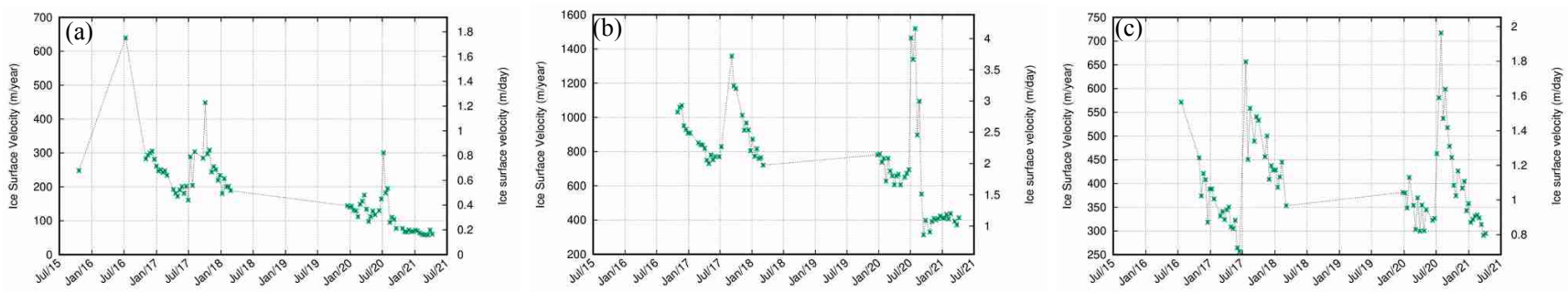

Figure 10: Franz-Josef-Land: time series of Sentinel-1 velocity for (a) Simony Glacier on McClintock Island (mean $183 \mathrm{~m} / \mathrm{a}$, mean summer $226 \mathrm{~m} / \mathrm{a}(+23.8 \%)$, mean winter $174 \mathrm{~m} / \mathrm{a}(-4.7 \%))$, (b) west-oriented glacier of the Tyndal Ice

Cap on Hall Island (mean $757 \mathrm{~m} / \mathrm{a}$, mean summer $922 \mathrm{~m} / \mathrm{a}(+21.8 \%)$, mean winter $706 \mathrm{~m} / \mathrm{a}(-6.7 \%)$ ) and (c) Moscow Ice Cap Glacier 3 (mean 400 m/a, mean summer 490 m/a (+22.6\%), mean winter 397 m/a (-7.6\%)).

\subsubsection{Severnaya Zemlya}

On Severnaya Zemlya, the very prominent surging glacier on Vavilov Ice Cap has a decreasing trend of velocity since 2017, with strong summer speed-up events (Figure 11a). The glacier to the north of the Karpinsky Ice Cap, which had significantly larger velocities in 1991 compared to 2020/2021, now shows a decreasing trend of velocities, again with very pronounced summer speed-up events (Figure 11b). For the Academy of Sciences Ice Cap, we selected one glacier with a relatively constant velocity and short-time speed-up events, that are possibly not captured in 2017 and 2018, because of the lower quality of summer ice velocity maps compared to those from winter (Figure 11c). For the 17 glaciers analysed over

Severnaya Zemlya with Sentinel-1 velocities larger than $100 \mathrm{~m} / \mathrm{a}$, the velocities in the winter period differed between $-13 \%$ and $+2 \%$ (average $-5 \%$ ) from the average annual velocities. The velocities in the summer period differed between $+27 \%$ and $-1 \%$ (average $+11 \%$ ) from the average annual velocities.
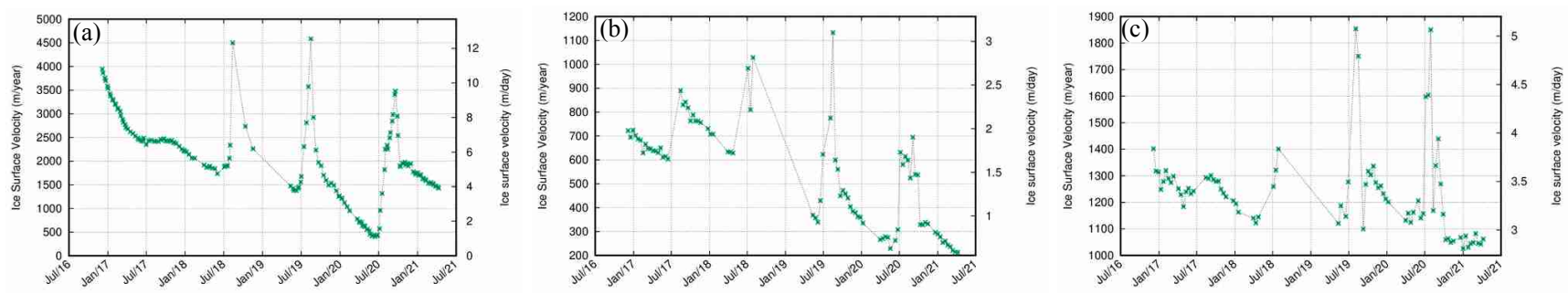

Figure 11: Severnaya Zemlya: time series of Sentinel-1 velocity for (a) Vavilov Ice Cap (mean 2062 m/a, mean summer $2117 \mathrm{~m} / \mathrm{a}(+2.6 \%)$, mean winter $2021 \mathrm{~m} / \mathrm{a}(-2.0 \%)$ ), (b) north of the Karpinsky Ice Cap (mean $541 \mathrm{~m} / \mathrm{a}$, mean 
https://doi.org/10.5194/essd-2022-44

Preprint. Discussion started: 17 February 2022

(c) Author(s) 2022. CC BY 4.0 License.

summer $650 \mathrm{~m} / \mathrm{a}(+\mathbf{2 0 . 1} \%)$, mean winter $488 \mathrm{~m} / \mathrm{a}(-9.8 \%)$ ) and (c) Academy of Sciences 6 (mean $1239 \mathrm{~m} / \mathrm{a}$, mean summer $1341 \mathrm{~m} / \mathrm{a}(+8.2 \%)$, mean winter $1189 \mathrm{~m} / \mathrm{a}(+4.0 \%))$.

\subsubsection{Svalbard}

405 For Svalbard, we again show a few examples of time series for glaciers having distinctly different patterns. Over this region, there are 12-day acquisitions from both Sentinel-1A/B satellites, and in general the time-series are denser than over the Russian High Arctic. Basin 3 has a decreasing trend of velocity since 2015, after the peak of the surge, with strong summer speed-up events (Figure 12a), similar to what is observed for the surging outlet glacier on Vavilov Ice Cap over Severnaya Zemlya (Figure 7a). For Negribreen (Figure 12b), we observe a full surge cycle, with a very strong increase in winter 2017/2018, followed by a slowly decreasing trend with summer speed-up events. Kronebreen (Figure 12c) and Hornbreen (Figure 12d), on the other hand, do not show long-term changes, but strong velocity peaks in summer over Kronebreen and towards October-November over Hornbreen. For Hinlopenbreen (Figure 12e), the decrease of velocity after the summer speed-up is much slower than for Kronebreen and Hornbreen, lasting a few months. For Idabreen (Figure 12f), maximum velocities are reached during the winter, slowly decreasing to reach the minima in summer. For the 30 glaciers analysed in our study over Svalbard with Sentinel-1 velocities larger than $100 \mathrm{~m} / \mathrm{a}$, the velocities in the winter period differed between $13 \%$ and $+14 \%$ (average 1\%) compared to the average annual velocities. The velocities in the summer period differed between $-33 \%$ and $+46 \%$ (average $-2 \%$ ) compared to the average annual velocities. The variability of ice surface velocities over Svalbard, also graphically summarised in Figure 14, is much larger than over the Russian High Arctic. It is worth noting that in our list of glaciers, we included only two surging glaciers, Basin 3 and Negribreen.
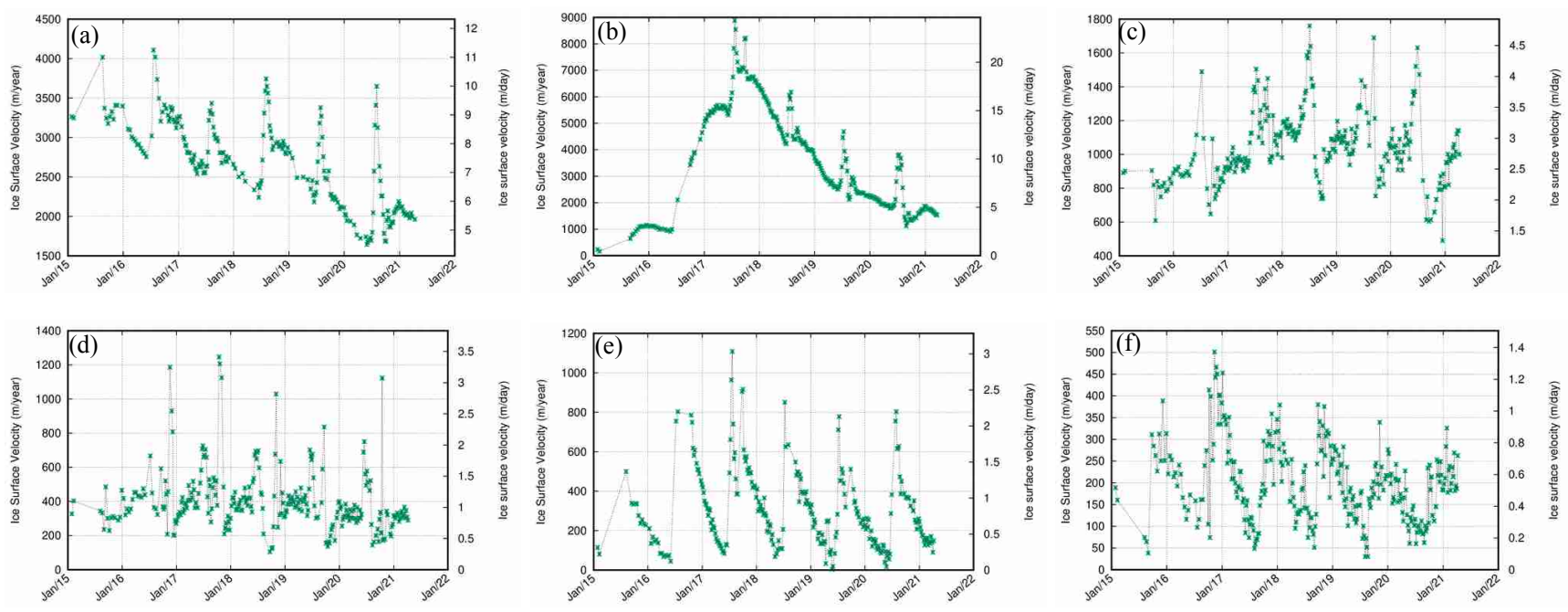

Figure 12: Svalbard: time series of Sentinel-1 velocity for (a) Basin 3 (mean $2650 \mathrm{~m} / \mathrm{a}$, mean summer $2787 \mathrm{~m} / \mathrm{a}$ (+5.2\%), mean winter $2537 \mathrm{~m} / \mathrm{a}(-4.2 \%)$ ), (b) Negribreen (mean $3148 \mathrm{~m} / \mathrm{a}$, mean summer $3668 \mathrm{~m} / \mathrm{a}(+16.5 \%)$, mean winter 2905 m/a (-7.7\%)), (c) Kronebreen (mean 1042 m/a, mean summer 1165 m/a (+11.8\%), mean winter 1004 m/a 

(mean 199 m/a, mean summer 133 m/a (-33.2\%), mean winter $227 \mathrm{~m} / \mathrm{a}(+14.2 \%))$.

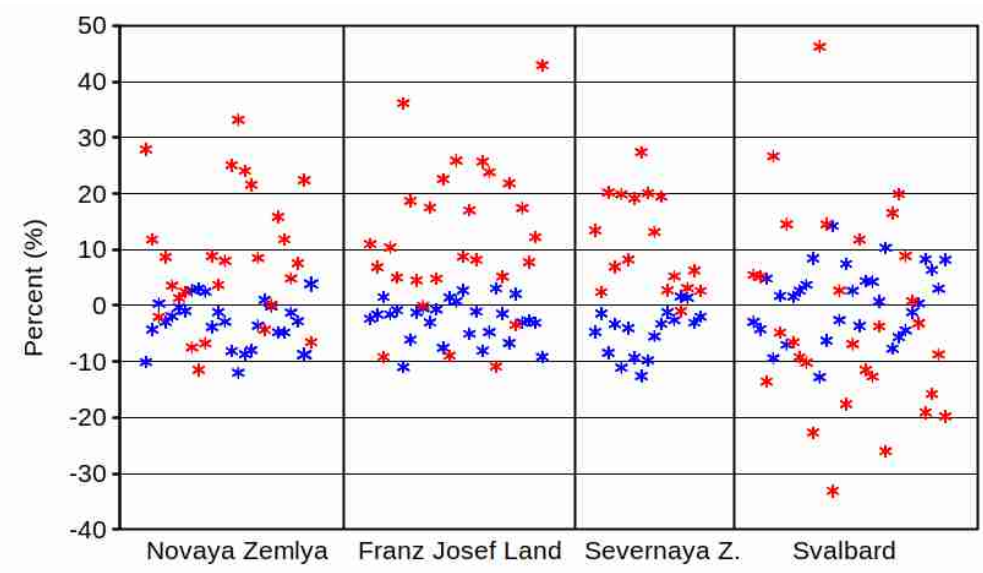

430 Figure 13: Differences between annual average ice surface velocity and winter (October-May, blue) and summer (June-September, red) averages for the glaciers analysed in our four study regions.

\subsection{Interpretation of the long-term trends}

We observed a general increase of winter velocities from the 1990's in the Eastern Arctic, along with a retreat of glacier fronts. Notable exceptions to this general pattern are surges, which are widespread over Svalbard but rarely found in the other three study regions. Indeed, for a couple of glaciers on Novaya Zemlya (e.g. Figures 9c), three glaciers on Severnaya Zemlya (e.g. Figures 11a, 11b) and more than ten glaciers on Svalbard (e.g. Figures 12a and 12b, the others not shown in this contribution but listed e.g., in Leclercq et al. (2021)), intra-annual trends in the Sentinel-1 ice surface velocity time-series dominate over inter-annual variability. Surges were not detected with our 1990's data. Few examples of surging glaciers as found in the literature (e.g., Monacobreen (Luckman et al., 2002) and Fridtjovbreen (Murray et al., 2003)) are missed, because they were asynchronous with our JERS-1 data coverage. At present, many more surging glaciers are observed over Svalbard than in the 1990's (Morris et al., 2020), making the interpretation of the long-term variability of ice surface velocity over this region challenging. It is expected that with the continued global temperature increase, the variability in the way glaciers respond to climate change will further increase. Some glaciers feature dynamic instabilities and discharge large amounts of ice, while others become dynamically less active and exhibit moderate rates of mass loss. As dynamic instabilities allow for larger, more rapid ice mass loss than surface melt, it is expected that ice discharge into the oceans will increase. Characteristic patterns of time series of ice surface velocities over dynamic instabilities will be analysed in future work. 
The dynamic response of land ice to climate forcing constitutes the main uncertainty in global sea level projections for the next century (Church et al., 2013; Martin and Adcroft, 2010). To address this knowledge gap, observations of the relative contribution of both surface mass balance and ice dynamics to the global mass losses are necessary. Using seven years of CryoSat-2 swath interferometric altimetry, Tepes et al. (2021) tracked changes in the volume of Arctic glaciers and ice caps and partitioned their losses into signals associated to atmospheric processes and glacier dynamics. They concluded that while surface ablation is responsible for $87 \%$ of losses across the Arctic, dynamic imbalance is increasing in the Barents and Kara

455 Sea regions, where it now accounts for $43 \%$ of total ice loss. The persistent incursion of warm North Atlantic Ocean water into the Arctic Ocean, associated with a northward shift of Atlantic climate, is thought to have a direct impact on sea ice extent and tidewater glacier dynamics (McMillan et al., 2014; Polyakov et al., 2017; Barton et al., 2018). However, the respective role of internal processes, commonly ascribed to glacier surges, and external climatic forcing in driving these dynamic instabilities remains largely unclear (McMillan et al., 2014; Dunse et al., 2015). Quantifying calving fluxes to the ocean, composed of ice discharge to the ocean and marine-terminus retreat under the assumption of negligible melting and sublimation for grounded tidewater termini, is important to partition the causes of glacier mass loss. In order to quantify the regional decadal average calving flux, spatially and temporally consistent datasets of ice surface velocity are required together with consistent datasets of glacier ice thickness and terminus position (Kochtitzky et al., submitted). Our mosaics of winter ice surface velocities for the 1990's over the Eastern Arctic, with uncertainties of generally less than \pm 20 m/a, can support the assessment of the past regional decadal average calving flux for this region.

\section{Conclusions}

We computed nearly complete mosaics of winter ice surface velocities over the Eastern Arctic from the 1990's, presented long-term trends compared to results from ALOS-1 PALSAR-1 in winter 2008-2011 and Sentinel-1 in winter 2020/2021, and analysed the seasonal variability from Sentinel-1 data to infer the representativeness of winter velocities compared to annual averages. In most of the cases, winter velocities are a good representative of mean annual velocities, as seasonal fluctuations are relatively small for non-surging glaciers, with an underestimation of less than $10 \%$, in particular over the Russian High Arctic. Summer velocities, on the other hand, can be significantly larger than the annual mean. Additionally, there are strong, short-time speed-up events during the summer period for many glaciers. We conclude that winter velocities give a better idea of long-term trends in speed, even if the spatial extend of the summer acceleration events, which can also be subject to long-term changes, is missed. Available ice surface velocity products based on Landsat- 8 optical data such as GoLive, which also provide regularly updated scene-pair velocity fields, are limited to periods of solar illumination, therefore missing the winter season. As we showed, these data are more subject to summer speed-up events and thus less suited to analyse long-term trends in velocity. In addition, these products are less accurate in the very slow-moving accumulation areas, as these regions are difficult for optical feature tracking due to low-feature surfaces. Best approaches to integrate results derived from satellite SAR and optical missions still need to be further investigated. 
https://doi.org/10.5194/essd-2022-44

Preprint. Discussion started: 17 February 2022

(c) Author(s) 2022. CC BY 4.0 License.

One of the crucial lessons learned from previous research on partitioning the causes of glacier mass loss is a severe problem with glacier velocity data and uncertainty of the calving flux estimation coming from this source. For an improved glacier monitoring strategy in the Eastern Arctic from Sentinel-1 SAR data, 6 days repeat is better suited than 12 days to retrieve high quality data, because time-series used to study dynamic instabilities are denser and the effects of ice and snow melting are less severe. In addition, acquisition gaps as occurred in 2018 and 2019 over Franz-Josef-Land should be avoided, as the Sentinel-1 time-series over this region (Figure 10) are of arduous interpretation. The spatial resolution of the IW Sentinel-1 SAR data (Table 1) is not optimal for studying ice surface velocity of Arctic glaciers and ice caps, but still acceptable as a compromise to the global acquisition strategy. Future L-band SAR missions such as NISAR (https://nisar.jpl.nasa.gov; last access: 7 September 2021), ALOS-4 (https://global.jaxa.jp/projects/sat/alos4; last access: 7 September 2021) or ROSE-L (https://www.esa.int/Our_Activities/Observing_the_Earth/Copernicus/Candidate_missions; last access: 7 September 2021) can complement the Sentinel-1 results.

\section{Data availability}

\section{Output data}

495 The ice surface velocity data set for the 1990's over the Eastern Arctic from satellite SAR data can be downloaded from https://doi.pangaea.de/10.1594/PANGAEA.938381 (Strozzi et. al. 2021).

\section{Input data}

JERS-1 SAR data are available from ESA as SLC at https://tpm-ds.eo.esa.int/socat/JERS1-SLC (last access: 6 September 2021) and from JAXA as RAW at https://gportal.jaxa.jp/gpr (last access: 6 September 2021). ERS-1/2 SAR data are 500 available from ESA as RAW at http://esar-ds.eo.esa.int/socat/SAR_IM_OP_Scenes (last access: 6 September 2021). ALOS1 PALSAR-1 RAW data are available from ESA at http://alos-ds.eo.esa.int/socat/ALOS PALSAR_FBS RAW 0P (last access: 6 September 2021), JAXA at https://gportal.jaxa.jp/gpr (last access: 6 September 2021), and ASF at https://search.asf.alaska.edu (last access: 6 September 2021). Sentinel-1 IW SLC data are available from Copernicus at https://scihub.copernicus.eu (last access: 6 September 2021).

505 The global TanDEM-X DEM at 3 arc second resolution is available at https://download.geoservice.dlr.de/TDM90 (last access: 6 September 2021). The digital elevation data derived from Soviet Union topographic maps of 1:100,000 and 1:200,000 scale are available at http://viewfinderpanoramas.org (last access: 6 September 2021).

The glacier outlines from summer satellite imagery spanning the period 2000-2010 for the Russian High Arctic (Moholdt et al., 2012) and Svalbard (Nuth et al., 2013) are available from the GLIMS glacier database at https://www.glims.org (last 510 access: 6 September 2021). Glacier outlines between 2013 and 2016 over Novaya Zemlya (Rastner et al., 2017) and from 2016 for Franz-Josef-Land (unpublished) are available from the GLIMS glacier database at https://www.glims.org_(last 
https://doi.org/10.5194/essd-2022-44

Preprint. Discussion started: 17 February 2022

(c) Author(s) 2022. CC BY 4.0 License.

(c) (i)

access: 6 September 2021). Glacier outlines from 2017 and 2018 for Svalbard (unpublished) can be provided upon request by the authors.

\section{Author contributions}

515 T.St., A.K. and F.P. designed the experiments; T.St. and A.W. processed most of the satellite SAR images, T.Sc. contributed with the analysis of the ERS-1/2 InSAR data over Svalbard; T.St. led the writing of the paper; all authors analysed the results and contributed to the redaction of the paper.

\section{Acknowledgments}

The research leading to these results received funding from the European Space Agency (ESA) within the Glaciers CCI project (Grant 4000127593/19/I-NB) and the EarthExplorer10 Harmony Mission Advisory Group, and from the Norwegian Space Centre project Copernicus Glacier Service for Norway (NIT.06.15.5). The study is a contribution to the Svalbard Integrated Arctic Earth Observing System SIOS. A sincere thanks to Nina Jones for her diligent proofreading of this article.

\section{References}

Barton, B. I., Lenn, Y.-D., and Lique, C.: Observed Atlantification of the Barents Sea Causes the Polar Front to Limit the Expansion of Winter Sea Ice, 48, 1849-1866, https://doi.org/10.1175/JPO-D-18-0003.1, 2018.

Benn, D. I., Jones, R. L., Luckman, A., Fürst, J. J., Hewitt, I., and Sommer, C.: Mass and enthalpy budget evolution during the surge of a polythermal glacier: a test of theory, J. Glaciol., 65, 717-731, https://doi.org/10.1017/jog.2019.63, 2019.

Blaszczyk, M., Jania, J., and Hagen, J.O.: Tidewater glaciers of Svalbard: Recent changes and estimates of calving fluxes. Polish Polar Research, 30(2), 85-142, 2009.

Burgess, E. W., Forster, R. R., and Larsen, C. F.: Flow velocities of Alaskan glaciers, Nat Commun, 4, 2146, https://doi.org/ $\underline{10.1038 / \text { ncomms3146, } 2013 .}$.

Church, J.A., et al. Climate change 2013: The physical science basis. In: Contribution of Working Group I to the Fifth Assessment Report of the Intergovernmental Panel on Climate Change (IPCC). Cambridge Univ. Press, Cambridge, 2013.

Dehecq, A., Gourmelen, N., and Trouve, E.: Deriving large-scale glacier velocities from a complete satellite archive: Application to the Pamir-Karakoram-Himalaya, Remote Sensing of Environment, 162, 55-66, https://doi.org/10.1016/j.rse.2015.01.031, 2015.

Dowdeswell, J. A., Bassford, R. P., Gorman, M. R., Williams, M., Glazovsky, A. F., Macheret, Y. Y., Shepherd, A. P., Vasilenko, Y. V., Savatyuguin, L. M., Hubberten, H.-W., and Miller, H.: Form and flow of the Academy of Sciences Ice 
https://doi.org/10.5194/essd-2022-44

Preprint. Discussion started: 17 February 2022

(c) Author(s) 2022. CC BY 4.0 License.

Cap, Severnaya Zemlya, Russian High Arctic, J. Geophys. Res., 107, EPM 5-1-EPM 5-15, https://doi.org/10.1029/2000JB000129, 2002.

Dunse, T., Schellenberger, T., Hagen, J. O., Kääb, A., Schuler, T. V., and Reijmer, C. H.: Glacier-surge mechanisms promoted by a hydro-thermodynamic feedback to summer melt, The Cryosphere, 9, 197-215, https://doi.org/10.5194/tc9-197-2015, 2015.

545 Fahnestock, M., Scambos, T., Moon, T., Gardner, A., Haran, T., and Klinger, M.: Rapid large-area mapping of ice flow using Landsat 8, Remote Sensing of Environment, 185, 84-94, https://doi.org/10.1016/j.rse.2015.11.023, 2016.

Flink, A. E., Noormets, R., Kirchner, N., Benn, D. I., Luckman, A., and Lovell, H.: The evolution of a submarine landform record following recent and multiple surges of Tunabreen glacier, Svalbard, Quaternary Science Reviews, 108, 37-50, https://doi.org/10.1016/j.quascirev.2014.11.006, 2015.

550 Friedl, P., Seehaus, T., and Braun, M.: Global time series and temporal mosaics of glacier surface velocities, derived from Sentinel-1 data, 1-33, https://doi.org/10.5194/essd-2021-106, 2021.

Gardner, A. S., Moholdt, G., Scambos, T., Fahnstock, M., Ligtenberg, S., van den Broeke, M., and Nilsson, J.: Increased West Antarctic and unchanged East Antarctic ice discharge over the last 7 years, The Cryosphere, 12, 521-547, https://doi.org/10.5194/tc-12-521-2018, 2018.

Glazovsky, A., Bushueva, I., and Nosenko, G., "Slow” surge of the Vavilov Ice Cap, Severnaya Zemlya. In Proceedings ofthe IASC Workshop on the Dynamics and Mass Balance of Arctic Glaciers, Obergurgl, Austria, 23-25 March 2015.

Hugonnet, R., McNabb, R., Berthier, E., Menounos, B., Nuth, C., Girod, L., Farinotti, D., Huss, M., Dussaillant, I., Brun, F., and Kääb, A.: Accelerated global glacier mass loss in the early twenty-first century, Nature, 592, 726-731, https://doi.org/10.1038/s41586-021-03436-z, 2021.

Kochtitzky, W., Copland, L., Van Wychen, W., Hugonnet., R., Hock, R., Dowdeswell, J., Benham, T., Strozzi, T., Glazovsky, A., Lavrentiev, I., Rounce, D., Millan, R., Cook, A., Dalton, A., Jiskoot, H., Cooley, J., Jania, J., and Navarro, F., Frontal ablation, the unquantified mass loss of marine-terminating glaciers, 2000-2020, Nature Communications, submitted.

Leclercq, P. W., Kääb, A., and Altena, B.: Brief Communication: Detection of glacier surge activity using cloud computing of Sentinel-1 radar data, The Cryosphere Discuss. [preprint], https://doi.org/10.5194/tc-2021-89, 2021.

Luckman, A., Murray, T., and Strozzi, T.: Surface flow evolution throughout a glacier surge measured by satellite radar interferometry, Geophys. Res. Lett., 29(23), 10.1-10.4, https://doi.org/10.1029/2001GL014570, 2002.

Martin, T. and Adcroft, A.: Parameterizing the fresh-water flux from land ice to ocean with interactive icebergs in a coupled climate model, Ocean Modelling, 34, 111-124, https://doi.org/10.1016/j.ocemod.2010.05.001, 2010.

570 McMillan, M., Shepherd, A., Gourmelen, N., Dehecq, A., Leeson, A., Ridout, A., Flament, T., Hogg, A., Gilbert, L., Benham, T., van den Broeke, M., Dowdeswell, J. A., Fettweis, X., Noël, B., and Strozzi, T.: Rapid dynamic activation of a marine-based Arctic ice cap: Ice cap dynamic activation, Geophys. Res. Lett., 41, 8902-8909, https://doi.org/10.1002/2014GL062255, 2014. 
https://doi.org/10.5194/essd-2022-44

Preprint. Discussion started: 17 February 2022

(c) Author(s) 2022. CC BY 4.0 License.

(c) (i)

Moholdt, G., Wouters, B., and Gardner, A. S.: Recent mass changes of glaciers in the Russian High Arctic, 39, https://doi.org/10.1029/2012GL051466, 2012.

Morris, A., Moholdt, G., and Gray, L.: Spread of Svalbard Glacier Mass Loss to Barents Sea Margins Revealed by CryoSat2, J. Geophys. Res. Earth Surf., 125, https://doi.org/10.1029/2019JF005357, 2020.

Murray, T., Luckman, A., Strozzi, T., and Nuttall, A.-M.: The initiation of glacier surging at Fridtjovbreen, Svalbard, Ann. Glaciol., 36, 110-116, https://doi.org/10.3189/172756403781816275, 2003.

Nagler, T., Rott, H., Hetzenecker, M., Wuite, J., and Potin, P.: The Sentinel-1 Mission: New Opportunities for Ice Sheet Observations, 7, 9371-9389, https://doi.org/10.3390/rs70709371, 2015.

Nuth, C., Kohler, J., König, M., von Deschwanden, A., Hagen, J. O., Kääb, A., Moholdt, G., and Pettersson, R.: Decadal changes from a multi-temporal glacier inventory of Svalbard, The Cryosphere, 7, 1603-1621, https://doi.org/10.5194/tc7-1603-2013, 2013.

Nuth, C., Gilbert, A., Köhler, A., McNabb, R., Schellenberger, T., Sevestre, H., Weidle, C., Girod, L., Luckman, A., and Kääb, A.: Dynamic vulnerability revealed in the collapse of an Arctic tidewater glacier, Sci Rep, 9, 5541, https://doi.org/ 10.1038/s41598-019-41117-0, 2019.

Paul, F., Bolch, T., Kääb, A., Nagler, T., Nuth, C., Scharrer, K., Shepherd, A., Strozzi, T., Ticconi, F., Bhambri, R., Berthier, E., Bevan, S., Gourmelen, N., Heid, T., Jeong, S., Kunz, M., Lauknes, T. R., Luckman, A., Merryman Boncori, J. P., Moholdt, G., Muir, A., Neelmeijer, J., Rankl, M., VanLooy, J., and Van Niel, T.: The glaciers climate change initiative: Methods for creating glacier area, elevation change and velocity products, Remote Sensing of Environment, 162, 408426, https://doi.org/10.1016/j.rse.2013.07.043, 2015.

Paul, F., Bolch, T., Briggs, K. Kääb, A., McMillan, M, McNabb, R., Nagler, T., Nuth, C., Rastner, P., Strozzi, T. and Wuite, J.: Error sources and guidelines for quality assessment of glacier area, elevation change, and velocity products derived from satellite data in the Glaciers_cci project, Remote Sensing of Environment, 203, 256-275, https://doi.org/10.1016/j.rse.2017.08.038, 2017.Paterson, W. S. B.: The physics of glaciers, 3rd ed., Pergamon, Oxford, OX, England; Tarrytown, N.Y., U.S.A, 480 pp., 1994.

Pohjola, V. A., Christoffersen, P., Kolondra, L., Moore, J. C., Pettersson, R., Schäfer, M., Strozzi, T., and Reijmer, C. H.: Spatial distribution and change in the surface ice velocity field of vestfonna ice cap, Nordaustlandet, Svalbard, $1995-$ 2010 using geodetic and satellite interferometry data, Geografiska Annaler Series A-Physical Geography, 93, 323-335, https://doi.org/10.1111/j.1468-0459.2011.00441.x, 2011.

Polyakov, I. V., Pnyushkov, A. V., Alkire, M. B., Ashik, I. M., Baumann, T. M., Carmack, E. C., Goszczko, I., Guthrie, J., Ivanov, V. V., Kanzow, T., Krishfield, R., Kwok, R., Sundfjord, A., Morison, J., Rember, R., and Yulin, A.: Greater role for Atlantic inflows on sea-ice loss in the Eurasian Basin of the Arctic Ocean, Science, 356, 285-291, https://doi.org/10.1126/science.aai8204, 2017.

Rastner, P., Strozzi, T., and Paul, F.: Fusion of Multi-Source Satellite Data and DEMs to Create a New Glacier Inventory for Novaya Zemlya, Remote Sensing, 9, 1122, https://doi.org/10.3390/rs9111122, 2017. 
Scambos, T., Fahnestock, M., Moon, T., Gardner, A., and Klinger, M., Global Land Ice Velocity Extraction from Landsat 8 (GoLIVE), Version 1, Boulder, Colorado USA, NSIDC: National Snow and Ice Data Center, http://dx.doi.org/10.7265/ N5ZP442B, 2016.

Schellenberger, T., Dunse, T., Kääb, A., Schuler, T. V., Hagen, J. O., and Reijmer, C. H.: Multi-year surface velocities and sea-level rise contribution of the Basin-3 and Basin-2 surges, Austfonna, Svalbard, Glaciers, The Cryosphere Discuss., https://doi.org/10.5194/tc-2017-5, 2017.

Schuler, T. V., Kohler, J., Elagina, N., Hagen, J. O. M., Hodson, A. J., Jania, J. A., Kääb, A. M., Luks, B., Małecki, J., Moholdt, G., Pohjola, V. A., Sobota, I., and Van Pelt, W. J. J.: Reconciling Svalbard Glacier Mass Balance, Front. Earth Sci., 8, 156, https://doi.org/10.3389/feart.2020.00156, 2020.

Strozzi, T., Luckman, A., Murray, T., Wegmuller, U., and Werner, C. L.: Glacier motion estimation using SAR offsettracking procedures, IEEE Trans. Geosci. Remote Sensing, 40, 2384-2391, https://doi.org/10.1109/TGRS.2002.805079, 2002.

620 Strozzi, T., Kouraev, A., Wiesmann, A., Wegmüller, U., Sharov, A., and Werner, C.: Estimation of Arctic glacier motion with satellite L-band SAR data, Remote Sensing of Environment, 112, 636-645, https://doi.org/10.1016/j.rse.2007.06.007, 2008.

Strozzi, T., Paul, F., Wiesmann, A., Schellenberger, T., and Kääb, A.: Circum-Arctic Changes in the Flow of Glaciers and Ice Caps from Satellite SAR Data between the 1990s and 2017, Remote Sensing, 9, 947, https://doi.org/10.3390/rs9090947, 2017.

Strozzi, T., Wiesmann, A., Kääb, A., Schellenberger, T., Paul, F.: Ice Surface Velocity in the Eastern Arctic from Past Spaceborne SAR Data. PANGAEA, https://doi.org/10.1594/PANGAEA.938381, 2021.

Sund, M., Lauknes, T. R., and Eiken, T.: Surge dynamics in the Nathorstbreen glacier system, Svalbard, The Cryosphere, 8 , 623-638, https://doi.org/10.5194/tc-8-623-2014, 2014.

630 Tepes, P., Gourmelen, N., Nienow, P., Tsamados, M., Shepherd, A., and Weissgerber, F.: Changes in elevation and mass of Arctic glaciers and ice caps, 2010-2017, Remote Sensing of Environment, 261, 112481, https://doi.org/10.1016/j.rse.2021.112481, 2021.

Wegmüller, U., Werner, C., Strozzi, T., and Wiesmann, A.: Ionospheric electron concentration effects on SAR and INSAR, Proceedings of IGARSS, Denver (USA), https://doi.org/10.1109/IGARSS.2006.956, 31 July- 4 August 2006.

635 Werner, C., Wegmuller, U., Strozzi, T., and Wiesmann, A.: Precision estimation of local offsets between pairs of SAR SLCs and detected SAR images, Proc. IEEE Int. Geosci. Remote Sens. Symp. (IGARSS), Seoul, Korea, 4803-4805, https://doi.org/10.1109/IGARSS.2005.1526747, 2005.

Willis, M. J., Melkonian, A. K., and Pritchard, M. E.: Outlet glacier response to the 2012 collapse of the Matusevich Ice Shelf, Severnaya Zemlya, Russian Arctic, J. Geophys. Res. Earth Surf., 120, 2040-2055, 640 https://doi.org/10.1002/2015JF003544, 2015. 
https://doi.org/10.5194/essd-2022-44

Preprint. Discussion started: 17 February 2022

(c) Author(s) 2022. CC BY 4.0 License.

(c) (1)

Willis, M. J., Zheng, W., Durkin, W. J., Pritchard, M. E., Ramage, J. M., Dowdeswell, J. A., Benham, T. J., Bassford, R. P., Stearns, L. A., Glazovsky, A. F., Macheret, Y. Y., and Porter, C. C.: Massive destabilization of an Arctic ice cap, Earth and Planetary Science Letters, 502, 146-155, https://doi.org/10.1016/j.epsl.2018.08.049, 2018.

Wouters, B., Gardner, A. S., and Moholdt, G.: Global Glacier Mass Loss During the GRACE Satellite Mission (2002-2016), Front. Earth Sci., 7, 96, https://doi.org/10.3389/feart.2019.00096, 2019.

Zemp, M., Huss, M., Thibert, E., Eckert, N., McNabb, R., Huber, J., Barandun, M., Machguth, H., Nussbaumer, S. U., Gärtner-Roer, I., Thomson, L., Paul, F., Maussion, F., Kutuzov, S., and Cogley, J. G.: Global glacier mass changes and their contributions to sea-level rise from 1961 to 2016, Nature, 568, 382-386, https://doi.org/10.1038/s41586-019-1071$\underline{0}, 2019$.

650 Zheng, W., Pritchard, M. E., Willis, M. J., and Stearns, L. A.: The Possible Transition From Glacial Surge to Ice Stream on Vavilov Ice Cap, Geophys. Res. Lett., 46, 13892-13902, https://doi.org/10.1029/2019GL084948, 2019. 


\section{Appendix A. Satellite data.}

Table A1. JERS-1 SAR data over Novaya Zemlya.

\begin{tabular}{|c|c|c|c|c|c|c|c|}
\hline Track_Frame & Orbit & Date 1 & Date 2 & Baseline (m) & Interval (d) & Stdev $(\mathbf{m} / \mathbf{a})$ & Percent (\%) \\
\hline 0239_0177 & DESC & 19980209 & 19980325 & 392.6 & 44 & 11.46 & 83.91 \\
\hline 0239_0176 & DESC & 19980209 & 19980325 & 401.1 & 44 & 13.33 & 39.06 \\
\hline 0239_0175 & DESC & 19980209 & 19980325 & 409.8 & 44 & 13.69 & 23.35 \\
\hline 0235_0177 & DESC & 19980205 & 19980321 & 363.6 & 44 & 7.77 & 93.04 \\
\hline 0235_0176 & DESC & 19980205 & 19980321 & 373.9 & 44 & 6.76 & 94.28 \\
\hline 0235_0175 & DESC & 19980205 & 19980321 & 384.2 & 44 & 9.83 & 90.97 \\
\hline 0235_0174 & DESC & 19980205 & 19980321 & 394.5 & 44 & 19.89 & 88.78 \\
\hline 0235_0173 & DESC & 19980205 & 19980321 & 404.8 & 44 & 29.67 & 79.87 \\
\hline 0235_0172 & DESC & 19980205 & 19980321 & 415.2 & 44 & 41.60 & 73.36 \\
\hline 0231_0174 & DESC & 19980201 & 19980317 & 400.5 & 44 & 11.58 & 79.90 \\
\hline 0231_0173 & DESC & 19980201 & 19980317 & 406.9 & 44 & 16.61 & 90.32 \\
\hline 0231_0172 & DESC & 19980201 & 19980317 & 413.2 & 44 & 25.21 & 86.61 \\
\hline $0228 \_0173$ & DESC & 19980129 & 19980314 & 347.5 & 44 & 23.94 & 81.51 \\
\hline 0228_0172 & DESC & 19980129 & 19980314 & 353.8 & 44 & 17.10 & 87.55 \\
\hline 0228_0171 & DESC & 19980129 & 19980314 & 360.1 & 44 & 41.28 & 67.08 \\
\hline 0220_0172 & DESC & 19980121 & 19980306 & -75.7 & 44 & 18.05 & 64.96 \\
\hline 0220_0171 & DESC & 19980121 & 19980306 & -52.6 & 44 & 20.33 & 87.21 \\
\hline 0220_0170 & DESC & 19980121 & 19980306 & -33.9 & 44 & 12.39 & 85.19 \\
\hline $0225 \_0172$ & DESC & 19980126 & 19980311 & 521.1 & 44 & 20.55 & 86.60 \\
\hline 0225_0171 & DESC & 19980126 & 19980311 & 520.7 & 44 & 33.96 & 80.77 \\
\hline 0225_0170 & DESC & 19980126 & 19980311 & 520.2 & 44 & 79.90 & 59.12 \\
\hline
\end{tabular}

655 Table A2. ALOS-1 PALSAR-1 data over Novaya Zemlya.

\begin{tabular}{|c|c|c|c|c|c|c|c|}
\hline Track_Frames & Orbit & Date 1 & Date 2 & Baseline (m) & Interval (d) & Stdev (m/a) & Percent (\%) \\
\hline $523 \_1510-1520$ & ASC & 20081211 & 20090126 & 723.4 & 46 & 33.48 & 88.94 \\
\hline $513 \_1520-1530$ & $\mathrm{ASC}$ & 20081225 & 20090209 & 844.1 & 46 & 31.89 & 93.68 \\
\hline $535 \_1460-1490$ & ASC & 20081231 & 20090215 & 850.4 & 46 & 9.95 & 92.01 \\
\hline 527 1500-1510 & $\mathrm{ASC}$ & 20090102 & 20090217 & 765.9 & 46 & 27.11 & 93.48 \\
\hline $519 \_1530-1540$ & ASC & 20090104 & 20090219 & 725.2 & 46 & 27.13 & 92.49 \\
\hline $525 \_1530-1540$ & $\mathrm{ASC}$ & 20090114 & 20090301 & 707.6 & 46 & 33.08 & 94.50 \\
\hline $517 \_1500-1520$ & ASC & 20090116 & 20090303 & 697.4 & 46 & 27.28 & 94.16 \\
\hline $509 \_1530-1540$ & ASC & 20090118 & 20090305 & 709.6 & 46 & 44.31 & 92.06 \\
\hline $539 \_1460$ & ASC & 20090122 & 20090309 & 750.5 & 46 & 5.56 & 96.44 \\
\hline
\end{tabular}


https://doi.org/10.5194/essd-2022-44

Preprint. Discussion started: 17 February 2022

(c) Author(s) 2022. CC BY 4.0 License.

\begin{tabular}{|l|l|l|l|l|l|l|l|}
\hline 531_1480-1510 & ASC & 20100314 & 20100429 & 359.9 & 46 & 19.00 & 93.46 \\
\hline
\end{tabular}

Table A3. Sentinel-1 data over Novaya Zemlya.

\begin{tabular}{|c|c|c|c|c|c|c|c|}
\hline Track & Orbit & Date 1 & Date 2 & Baseline (m) & Interval (d) & Stdev (m/a) & Percent (\%) \\
\hline 6 & DESC & 20210213 & 20210225 & -66.7 & 12 & 43.63 & 97.26 \\
\hline 50 & DESC & 20210204 & 20210216 & 36.5 & 12 & 25.23 & 96.51 \\
\hline
\end{tabular}

Table A4. JERS-1 SAR data over Franz-Josef-Land.

\begin{tabular}{|c|c|c|c|c|c|c|c|}
\hline Track_Frame & Orbit & Date 1 & Date 2 & Baseline (m) & Interval (d) & $\operatorname{Stdev}(\mathbf{m} / \mathbf{a})$ & Percent (\%) \\
\hline 0249_0161 & DESC & 19980106 & 19980219 & 192.4 & 44 & 9.39 & 77.48 \\
\hline $0249 \_0162$ & DESC & 19980106 & 19980219 & 186.0 & 44 & 13.89 & 93.86 \\
\hline 0249_0163 & DESC & 19980106 & 19980219 & 179.6 & 44 & 34.64 & 93.41 \\
\hline 0249_0164 & DESC & 19980106 & 19980219 & 173.1 & 44 & 31.93 & 87.16 \\
\hline $0249 \_0165$ & DESC & 19980106 & 19980219 & 166.5 & 44 & 15.51 & 74.87 \\
\hline 0255_0161 & DESC & 19980112 & 19980225 & -53.8 & 44 & 24.42 & 83.69 \\
\hline $0255 \_0162$ & DESC & 19980112 & 19980225 & -74.0 & 44 & 23.3 & 85.87 \\
\hline 0255_0163 & DESC & 19980112 & 19980225 & -94.3 & 44 & 22.64 & 88.15 \\
\hline 0255_0164 & DESC & 19980112 & 19980225 & -114.3 & 44 & 18.29 & 90.07 \\
\hline 0260_0161 & DESC & 19980302 & 19980529 & 1244.8 & 88 & 21.04 & 93.68 \\
\hline 0260_0162 & DESC & 19980302 & 19980529 & 1309.0 & 88 & 15.65 & 89.58 \\
\hline 0260_0163 & DESC & 19980302 & 19980529 & 1372.0 & 88 & 15.57 & 88.31 \\
\hline 0260_0164 & DESC & 19980302 & 19980529 & 1435.8 & 88 & 15.15 & 94.43 \\
\hline 0260_0165 & DESC & 19980302 & 19980529 & 1499.5 & 88 & 24.04 & 92.09 \\
\hline 0270_0162 & DESC & 19980312 & 19980425 & 350.7 & 44 & 18.41 & 96.44 \\
\hline 0270_0163 & DESC & 19980312 & 19980425 & 338.7 & 44 & 26.2 & 84.39 \\
\hline 0270_0164 & DESC & 19980312 & 19980425 & 326.7 & 44 & 26.8 & 89.66 \\
\hline 0267_0163 & DESC & 19960404 & 19960518 & 529.7 & 44 & 24.09 & 93.70 \\
\hline 0267_0164 & DESC & 19960404 & 19960518 & 556.4 & 44 & 23.72 & 92.86 \\
\hline 0270_0163 & DESC & 19960407 & 19960521 & 528.7 & 44 & 27.3 & 56.30 \\
\hline 0279_0163 & DESC & 19971109 & 19971223 & 979.6 & 44 & 27.64 & 75.08 \\
\hline
\end{tabular}

Table A5. ERS-1 SAR data over Franz-Josef-Land.

\begin{tabular}{|c|c|c|c|c|c|c|c|}
\hline Track_Frame & Orbit & Date 1 & Date 2 & Baseline (m) & Interval (d) & Stdev (m/a) & Percent (\%) \\
\hline 36_1944 & DESC & 19911108 & 19911117 & 79.7 & 9 & 52.69 & 94.92 \\
\hline $40 \_1647$ & ASC & 19911012 & 19911021 & 219.0 & 9 & 53.22 & 74.29 \\
\hline 40_1647 & ASC & 19911021 & 19911102 & 208.8 & 12 & 34.67 & 82.51 \\
\hline
\end{tabular}


https://doi.org/10.5194/essd-2022-44

Preprint. Discussion started: 17 February 2022

(c) Author(s) 2022. CC BY 4.0 License.

Table A6. ALOS-1 PALSAR-1 data over Franz-Josef-Land.

\begin{tabular}{|c|c|c|c|c|c|c|c|}
\hline Track_Frames & Orbit & Date 1 & Date 2 & Baseline (m) & Interval (d) & Stdev (m/a) & Percent (\%) \\
\hline 526_1610-1630 & ASC & 20101222 & 20110206 & 824.4 & 46 & 31.14 & 92.92 \\
\hline 522_1610-1620 & ASC & 20110302 & 20110417 & 593.5 & 46 & 18.72 & 92.50 \\
\hline
\end{tabular}

Table A7. Sentinel-1 SAR data over Franz-Josef-Land.

\begin{tabular}{|c|c|c|c|c|c|c|c|}
\hline Track & Orbit & Date 1 & Date 2 & Baseline (m) & Interval (d) & Stdev (m/a) & Percent (\%) \\
\hline 36 & DESC & 20210110 & 20210122 & -60.5 & 12 & 32.59 & 94.0689 \\
\hline 167 & DESC & 20210131 & 20210212 & 54.0 & 12 & 33.49 & 97.7057 \\
\hline
\end{tabular}

Table A8. ERS-1 data over Severnaya Zemlya.

\begin{tabular}{|c|c|c|c|c|c|c|c|}
\hline Track_Frame & Orbit & Date 1 & Date 2 & Baseline (m) & Interval (d) & Stdev (m/a) & Percent (\%) \\
\hline $10 \_1642$ & ASC & 19920302 & 19920320 & 361.7 & 18 & 41.35 & 3.11 \\
\hline $10 \_1658$ & ASC & 19920302 & 19920320 & 357.4 & 18 & 64.98 & 38.54 \\
\hline $10 \_1614$ & ASC & 19920207 & 19920219 & 143.0 & 12 & 69.12 & 81.95 \\
\hline $10 \_1629$ & ASC & 19920207 & 19920219 & 137.1 & 12 & 44.87 & 94.33 \\
\hline $10 \_1642$ & ASC & 19920207 & 19920219 & 129.7 & 12 & 19.11 & 91.23 \\
\hline 39_1603 & ASC & 19911018 & 19911102 & 365.7 & 15 & 50.64 & 45.42 \\
\hline 39_1611 & ASC & 19911018 & 19911102 & 391.2 & 15 & 45.85 & 72.83 \\
\hline 39_1629 & ASC & 19911018 & 19911102 & 416.7 & 15 & 36.21 & 39.21 \\
\hline
\end{tabular}

Table A9. Sentinel-1 data over Severnaya Zemlya.

\begin{tabular}{|c|c|c|c|c|c|c|c|}
\hline Track & Orbit & Date 1 & Date 2 & Baseline (m) & Interval (d) & Stdev (m/a) & Percent (\%) \\
\hline 49 & DESC & 20201218 & 20201230 & 70.7 & 12 & 24.87 & 90.62 \\
\hline 49 & DESC & 20210123 & 20210204 & -25.4 & 12 & 24.42 & 91.24 \\
\hline 5 & DESC & 20201215 & 20201227 & -57.6 & 12 & 21.80 & 92.26 \\
\hline 5 & DESC & 20210213 & 20210225 & -64.6 & 12 & 22.93 & 89.61 \\
\hline
\end{tabular}

Table A10. JERS-1 data over Svalbard.

\begin{tabular}{|c|c|c|c|c|c|c|c|}
\hline Track_Frames & Orbit & Date 1 & Date 2 & Baseline (m) & Interval (d) & Stdev (m/a) & Percent (\%) \\
\hline 0293_0164 & DESC & 19971123 & 19980106 & 916.1 & 44 & 0.00 & 85.09 \\
\hline $0306 \_0169$ & DESC & 19971206 & 19980119 & 809.8 & 44 & 19.22 & 71.20 \\
\hline $0306 \_0168$ & DESC & 19971206 & 19980119 & 801.4 & 44 & 14.49 & 82.19 \\
\hline $0306 \_0167$ & DESC & 19971206 & 19980119 & 792.1 & 44 & 0.00 & 0.52 \\
\hline $0306 \_0166$ & DESC & 19971206 & 19980119 & 783.5 & 44 & 0.00 & 53.80 \\
\hline $0306 \_0165$ & DESC & 19971206 & 19980119 & 775.0 & 44 & 21.55 & 65.85 \\
\hline
\end{tabular}




\begin{tabular}{|c|c|c|c|c|c|c|c|}
\hline 0306_0164 & DESC & 19971206 & 19980119 & 766.3 & 44 & 49.47 & 83.40 \\
\hline $0308 \_0164$ & DESC & 19971208 & 19980121 & 548.3 & 44 & 32.75 & 82.95 \\
\hline 0308_0165 & DESC & 19971208 & 19980121 & 548.2 & 44 & 20.32 & 82.19 \\
\hline $0308 \_0166$ & DESC & 19971208 & 19980121 & 547.9 & 44 & 0.00 & 74.55 \\
\hline $0308 \_0167$ & DESC & 19971208 & 19980121 & 547.6 & 44 & 28.90 & 59.01 \\
\hline 0308_0168 & DESC & 19971208 & 19980121 & 547.3 & 44 & 14.20 & 77.82 \\
\hline 0308_0169 & DESC & 19971208 & 19980121 & 546.8 & 44 & 15.32 & 79.40 \\
\hline 0312_0164 & DESC & 19971212 & 19980125 & 323.7 & 44 & 11.67 & 85.75 \\
\hline 0312_0165 & DESC & 19971212 & 19980125 & 306.9 & 44 & 8.43 & 82.31 \\
\hline 0312_0166 & DESC & 19971212 & 19980125 & 290.2 & 44 & 10.43 & 75.17 \\
\hline 0312_0167 & DESC & 19971212 & 19980125 & 273.1 & 44 & 16.07 & 65.54 \\
\hline 0312_0168 & DESC & 19971212 & 19980125 & 256.7 & 44 & 19.99 & 38.73 \\
\hline 0312_0169 & DESC & 19971212 & 19980125 & 239.6 & 44 & 49.90 & 48.21 \\
\hline 0312_0170 & DESC & 19971212 & 19980125 & 222.7 & 44 & 64.26 & 48.37 \\
\hline $0312 \_0171$ & DESC & 19971212 & 19980125 & 205.6 & 44 & 64.55 & 66.12 \\
\hline 0314_0167 & DESC & 19940205 & 19940321 & 804.6 & 44 & 14.19 & 93.70 \\
\hline 0314_0166 & DESC & 19940205 & 19940321 & 809.6 & 44 & 14.53 & 101.87 \\
\hline 0314_0170 & DESC & 19971214 & 19980127 & 261.0 & 44 & 34.47 & 77.07 \\
\hline 0314_0169 & DESC & 19971214 & 19980127 & 270.8 & 44 & 19.96 & 80.71 \\
\hline 0314_0168 & DESC & 19971214 & 19980127 & 280.5 & 44 & 21.60 & 78.70 \\
\hline 0314_0167 & DESC & 19971214 & 19980127 & 290.2 & 44 & 14.79 & 76.72 \\
\hline 0314_0166 & DESC & 19971214 & 19980127 & 299.9 & 44 & 12.53 & 74.74 \\
\hline 0314_0165 & DESC & 19971214 & 19980127 & 309.6 & 44 & 8.83 & 84.45 \\
\hline 0314_0164 & DESC & 19971214 & 19980127 & 319.1 & 44 & 8.21 & 88.91 \\
\hline 0316_0170-68 & DESC & 19940323 & 19940506 & 352.1 & 44 & 14.64 & 51.66 \\
\hline 0316_0166-64 & DESC & 19940323 & 19940506 & 360.2 & 44 & 21.99 & 84.47 \\
\hline $0328 \_0167$ & DESC & 19971228 & 19980210 & 11.5 & 44 & 9.69 & 71.59 \\
\hline $0328 \_0166$ & DESC & 19971228 & 19980210 & -9.1 & 44 & 18.79 & 88.30 \\
\hline $0328 \_0165$ & DESC & 19971228 & 19980210 & -24.6 & 44 & 15.07 & 90.16 \\
\hline $0328 \_0167$ & DESC & 19980210 & 19980326 & 343.1 & 44 & 24.72 & 78.62 \\
\hline $0328 \_0166$ & DESC & 19980210 & 19980326 & 358.1 & 44 & 21.76 & 88.94 \\
\hline $0328 \_0165$ & DESC & 19980210 & 19980326 & 373.7 & 44 & 30.18 & 72.05 \\
\hline 0330_0167 & DESC & 19971116 & 19971230 & 1247.2 & 44 & 30.75 & 78.57 \\
\hline 0330_0166 & DESC & 19971116 & 19971230 & 1220.5 & 44 & 26.84 & 84.11 \\
\hline 0330_0165 & DESC & 19971116 & 19971230 & 1193.2 & 44 & 18.16 & 87.14 \\
\hline
\end{tabular}


https://doi.org/10.5194/essd-2022-44

Preprint. Discussion started: 17 February 2022

(c) Author(s) 2022. CC BY 4.0 License.

Table A11. ERS-1/2 InSAR data over Svalbard.

\begin{tabular}{|c|c|c|c|c|c|c|}
\hline Track & Frames & Orbit & Date 1 & Date 2 & Baseline (m) \\
\hline 70 & 1629 & ASC & 19951215 & 19951216 & 60 \\
\hline 70 & 1629 & ASC & 19960119 & 19960120 & 229 \\
\hline 80 & $1959-1977$ & DESC & 19951216 & 19951217 & -48 \\
\hline 80 & $1959-1977$ & DESC & 19960120 & 19960121 & 205 & 141 \\
\hline 199 & $1617-1635$ & ASC & 19951224 & 19951225 & 117 \\
\hline 199 & $1617-1635$ & ASC & 19960128 & 19960129 & 1 \\
\hline 495 & $953-1971$ & DESC & 19951210 & 19951211 & 30 \\
\hline 495 & $953-1971$ & DESC & 19960114 & 19960115 & 46 \\
\hline 42 & 1575 & ASC & 19971217 & 19971218 & 118 \\
\hline 452 & 2025 & DESC & 19960321 & 19960322 & 1 \\
\hline 185 & 1611 & ASC & 19951226 & 19951227 & 1 \\
\hline 166 & 1989 & DESC & 19960405 & 19960406 & 109 \\
\hline
\end{tabular}

Table A12. ERS-1 data over Svalbard.

\begin{tabular}{|c|c|c|c|c|c|c|c|}
\hline Track_Frame & Orbit & Date 1 & Date 2 & Baseline (m) & Interval (d) & Stdev (m/a) & Percent (\%) \\
\hline 23_1953 & DESC & 19920103 & 19920115 & 93.3 & 12 & 18.85 & 48.07 \\
\hline 23_1971 & DESC & 19920103 & 19920115 & 75.4 & 12 & 24.37 & 64.72 \\
\hline 23_1989 & DESC & 19920103 & 19920115 & 57.4 & 12 & 27.95 & 57.57 \\
\hline 23_2007 & DESC & 19920103 & 19920115 & 39.5 & 12 & 28.65 & 72.15 \\
\hline 23_2025 & DESC & 19920103 & 19920115 & 21.4 & 12 & 46.56 & 58.13 \\
\hline
\end{tabular}

Table A13. ALOS-1 PALSAR-1 data over Svalbard.

\begin{tabular}{|c|c|c|c|c|c|c|c|}
\hline Track_Frames & Orbit & Date 1 & Date 2 & Baseline (m) & Interval (d) & Stdev (m/a) & Percent (\%) \\
\hline 576_1600-1620 & ASC & 20080105 & 20080220 & 971.0 & 46 & 7.95 & 72.35 \\
\hline $583 \_1600-1610$ & ASC & 20080201 & 20080318 & 677.5 & 46 & 8.89 & 95.36 \\
\hline $586 \_1560$ & ASC & 20101114 & 20110214 & 1420.9 & 92 & 12.60 & 60.39 \\
\hline 586_1560-1570 & ASC & 20110104 & 20110219 & 872.3 & 46 & 3.67 & 91.80 \\
\hline 595_1560-1570 & ASC & 20110114 & 20110301 & 748.3 & 46 & 15.98 & 93.11 \\
\hline
\end{tabular}

680 Table A14. Sentinel-1 data over Svalbard.

\begin{tabular}{|c|c|c|c|c|c|c|c|}
\hline Track & Orbit & Date 1 & Date 2 & Baseline (m) & Interval (d) & Stdev (m/a) & Percent (\%) \\
\hline 14 & ASC & 20210120 & 20210201 & 50.2 & 12 & 13.59 & 94.37 \\
\hline 174 & ASC & 20210131 & 20210212 & 55.7 & 12 & 13.32 & 89.79 \\
\hline 174 & ASC & 20210206 & 20210212 & 84.0 & 6 & 21.74 & 96.62 \\
\hline
\end{tabular}




\section{Appendix B. Glacier's statistics.}

Table B1. Novaya Zemlya: statistics for time series of Sentinel-1 velocity 2015-2021.

\begin{tabular}{|c|c|c|c|c|c|c|c|c|c|}
\hline Name & Long. & Lat. & $\begin{array}{l}\text { Mean } \\
\text { Year }\end{array}$ & $\begin{array}{l}\text { Max } \\
\text { Year }\end{array}$ & $\begin{array}{l}\text { Min } \\
\text { Year }\end{array}$ & $\begin{array}{c}\text { Mean } \\
\text { Summer }\end{array}$ & $\begin{array}{l}\text { Percent } \\
\text { Summer }\end{array}$ & $\begin{array}{c}\text { Mean } \\
\text { Winter }\end{array}$ & $\begin{array}{l}\text { Percent } \\
\text { Winter }\end{array}$ \\
\hline Severny_1 & 746764 & 8545276 & 396 & 1252 & 79 & 507 & 27.9 & 356 & -10.1 \\
\hline Severny_2 & 741328 & 8530470 & 661 & 1034 & 428 & 739 & 11.8 & 632 & -4.3 \\
\hline Severny_3 & 739259 & 8505718 & 676 & 1254 & 416 & 662 & -2.0 & 679 & 0.3 \\
\hline Vize_4 & 714375 & 8498416 & 456 & 781 & 165 & 496 & 8.7 & 443 & -2.9 \\
\hline Severny_5 & 706501 & 8485936 & 630 & 1030 & 312 & 652 & 3.5 & 617 & -1.9 \\
\hline Severny_6 & 694115 & 8479524 & 470 & 1015 & 246 & 476 & 1.3 & 469 & -0.3 \\
\hline Severny_7 & 689392 & 8475873 & 738 & 1017 & 461 & 756 & 2.5 & 731 & -1.0 \\
\hline Severny_8 & 671672 & 8472142 & 627 & 907 & 346 & 580 & -7.5 & 644 & 2.7 \\
\hline Severny_9 & 662782 & 8464880 & 838 & 1465 & 374 & 742 & -11.5 & 864 & 3.1 \\
\hline Shokalskiy_10 & 650280 & 8460077 & 719 & 1064 & 445 & 671 & -6.8 & 737 & 2.5 \\
\hline Chernyshev_11 & 605924 & 8440027 & 553 & 928 & 282 & 601 & 8.8 & 531 & -3.9 \\
\hline Krayniy_Popov_12 & 580108 & 8426112 & 581 & 981 & 238 & 602 & 3.7 & 574 & -1.2 \\
\hline Krivosheina_13 & 551729 & 8407070 & 690 & 1239 & 497 & 746 & 8.0 & 670 & -2.9 \\
\hline Vilkitskiy_14 & 542025 & 8392240 & 440 & 1066 & 237 & 550 & 25.1 & 404 & -8.1 \\
\hline Severny_15 & 537964 & 8386298 & 340 & 803 & 203 & 453 & 33.2 & 299 & -12.0 \\
\hline Nordenskiold_16 & 528439 & 8360938 & 481 & 1100 & 297 & 597 & 24.1 & 439 & -8.7 \\
\hline Glazov_17 & 502583 & 8348119 & 357 & 788 & 230 & 434 & 21.6 & 329 & -8.0 \\
\hline Nizkiy_18 & 487264 & 8328771 & 235 & 427 & 170 & 256 & 8.5 & 227 & -3.6 \\
\hline Severny_92 & 510353 & 8234169 & 162 & 260 & 90 & 155 & -4.3 & 164 & 1.0 \\
\hline Severny_93 & 534855 & 8274953 & 118 & 225 & 21 & 118 & 0.1 & 117 & -0.2 \\
\hline Severny_94 & 583790 & 8326135 & 277 & 1258 & 116 & 320 & 15.8 & 263 & -4.8 \\
\hline Vylki_Shury_95 & 615505 & 8350781 & 250 & 435 & 189 & 280 & 11.8 & 238 & -4.8 \\
\hline Severny_96 & 636103 & 8379058 & 441 & 592 & 285 & 462 & 4.8 & 435 & -1.3 \\
\hline Moshchnyy_97 & 659380 & 8389476 & 388 & 600 & 236 & 417 & 7.6 & 377 & -2.8 \\
\hline Severny_98 & 700615 & 8418170 & 212 & 451 & 37 & 260 & 22.4 & 194 & -8.8 \\
\hline Severny_99 & 745978 & 8453055 & 159 & 592 & 23 & 149 & -6.6 & 166 & 3.9 \\
\hline
\end{tabular}


https://doi.org/10.5194/essd-2022-44

Preprint. Discussion started: 17 February 2022

(c) Author(s) 2022. CC BY 4.0 License.

685 Table B2. Franz-Josef-Land: statistics for time series of Sentinel-1 velocity 2015-2021.

\begin{tabular}{|c|c|c|c|c|c|c|c|c|c|}
\hline Name & Long. & Lat. & $\begin{array}{l}\text { Mean } \\
\text { Year }\end{array}$ & $\begin{array}{l}\text { Max } \\
\text { Year }\end{array}$ & $\begin{array}{l}\text { Min } \\
\text { Year }\end{array}$ & $\begin{array}{c}\text { Mean } \\
\text { Summer }\end{array}$ & $\begin{array}{l}\text { Percent } \\
\text { Summer }\end{array}$ & $\begin{array}{c}\text { Mean } \\
\text { Winter }\end{array}$ & $\begin{array}{l}\text { Percent } \\
\text { Winter }\end{array}$ \\
\hline Brousilov_1 & 366902 & 8962633 & 369 & 545 & 230 & 409 & 11,0 & 360 & $-2,4$ \\
\hline Brousilov_2 & 373548 & 8946717 & 398 & 648 & 256 & 426 & 6,9 & 392 & $-1,6$ \\
\hline Brousilov_3 & 380278 & 8968170 & 239 & 596 & 55 & 217 & $-9,2$ & 243 & 1,5 \\
\hline Brousilov_4 & 349663 & 8945647 & 236 & 341 & 87 & 261 & 10,4 & 232 & $-1,6$ \\
\hline Champ & 498831 & 8956263 & 138 & 292 & 36 & 145 & 5,0 & 137 & $-0,9$ \\
\hline Chernysheva & 554269 & 8882395 & 236 & 1130 & 133 & 321 & 36,1 & 209 & $-11,0$ \\
\hline Forbes & 523208 & 8977770 & 113 & 290 & 52 & 134 & 18,7 & 106 & $-6,1$ \\
\hline Luigi & 469416 & 8973739 & 158 & 406 & 8 & 165 & 4,5 & 156 & $-1,3$ \\
\hline Moon_4 & 308002 & 8975620 & 303 & 585 & 151 & 302 & $\mathbf{0 , 0}$ & 301 & $-0,5$ \\
\hline Moscow_1 & 515965 & 8902160 & 207 & 414 & 100 & 243 & 17,5 & 201 & $-3,0$ \\
\hline Moscow_2 & 527584 & 8917124 & 237 & 384 & 83 & 248 & 4,8 & 235 & $-0,7$ \\
\hline Moscow_3 & 515265 & 8933468 & 400 & 717 & 257 & 490 & 22,6 & 370 & $-7,6$ \\
\hline Northbrook_2 & 387401 & 8883086 & 228 & 389 & 10 & 208 & $-9,0$ & 231 & 1,4 \\
\hline Rudolph_Island_1 & 535877 & 9081462 & 207 & 1493 & 79 & 261 & 25,9 & 209 & 0,7 \\
\hline Rudolph_Island_2 & 528215 & 9074816 & 166 & 1016 & 21 & 180 & 8,7 & 170 & 2,7 \\
\hline Salisbury_1 & 512992 & 8966700 & 235 & 705 & 89 & 275 & 17,0 & 223 & $-5,0$ \\
\hline Samoylovitch_1 & 518092 & 9047154 & 267 & 454 & 102 & 289 & 8,2 & 264 & $-1,1$ \\
\hline Simony_1 & 501600 & 8904048 & 188 & 377 & 52 & 236 & 25,7 & 172 & $-8,1$ \\
\hline Simony_3 & 499786 & 8891447 & 184 & 640 & 58 & 226 & 23.8 & 174 & -4.7 \\
\hline Tyndall_2 & 581555 & 8938802 & 396 & 2150 & 196 & 353 & $-10,9$ & 408 & 3,1 \\
\hline Tyndall_3 & 558992 & 8934430 & 241 & 396 & 146 & 253 & 5,2 & 237 & $-1,5$ \\
\hline Tyndall_4 & 544475 & 8950346 & 757 & 1519 & 313 & 922 & 21,8 & 706 & $-6,7$ \\
\hline Tyndall_6 & 559866 & 8970110 & 329 & 737 & 92 & 317 & $-3,5$ & 335 & 2,1 \\
\hline Tyndall_7 & 575083 & 8975183 & 346 & 627 & 187 & 406 & 17,4 & 335 & $-3,0$ \\
\hline Vostok_1 & 561661 & 9001031 & 297 & 414 & 185 & 320 & 7,7 & 289 & $-2,7$ \\
\hline Vostok_2 & 575999 & 8994078 & 115 & 243 & 61 & 129 & 12,2 & 112 & $-3,1$ \\
\hline Vostok_3 & 562830 & 8985155 & 79 & 306 & 13 & 113 & 42,9 & 72 & $-9,2$ \\
\hline
\end{tabular}


https://doi.org/10.5194/essd-2022-44

Preprint. Discussion started: 17 February 2022

(c) Author(s) 2022. CC BY 4.0 License.

(c) (1)

Table B3. Severnaya Zemlya: statistics for time series of Sentinel-1 velocity 2015-2021.

\begin{tabular}{|c|c|c|c|c|c|c|c|c|c|}
\hline Name & Long. & Lat. & $\begin{array}{l}\text { Mean } \\
\text { Year }\end{array}$ & $\begin{array}{l}\text { Max } \\
\text { Year }\end{array}$ & $\begin{array}{l}\text { Min } \\
\text { Year }\end{array}$ & $\begin{array}{c}\text { Mean } \\
\text { Summer }\end{array}$ & $\begin{array}{c}\text { Percent } \\
\text { Summer }\end{array}$ & $\begin{array}{c}\text { Mean } \\
\text { Winter }\end{array}$ & $\begin{array}{l}\text { Percent } \\
\text { Winter }\end{array}$ \\
\hline Academy Sciences 1 & 463595 & 8946216 & 449 & 783 & 329 & 509 & 13,4 & 428 & $-4,7$ \\
\hline Academy Sciences 2 & 467049 & 8929805 & 1092 & 1347 & 968 & 1118 & 2,4 & 1076 & $-1,4$ \\
\hline Academy Sciences 3 & 446085 & 8907872 & 302 & 522 & 164 & 363 & 20,2 & 277 & $-8,5$ \\
\hline Academy Sciences 4 & 438899 & 8907977 & 1985 & 3909 & 1095 & 2122 & 6,9 & 1919 & $-3,3$ \\
\hline Academy Sciences 5 & 434144 & 8905336 & 230 & 449 & 114 & 275 & 19,9 & 204 & $-11,1$ \\
\hline Academy Sciences 6 & 419184 & 8899208 & 1239 & 1854 & 1026 & 1341 & 8,2 & 1189 & $-4,0$ \\
\hline Academy Sciences 7 & 374753 & 8916934 & 220 & 564 & 113 & 262 & 19,2 & 199 & $-9,3$ \\
\hline Karpinsky 1 & 481328 & 8860608 & 225 & 576 & 68 & 286 & 27,4 & 196 & $-12,6$ \\
\hline Karpinsky 2 & 487193 & 8862193 & 541 & 1133 & 213 & 650 & 20,1 & 488 & $-9,8$ \\
\hline Karpinsky 3 & 503943 & 8804018 & 176 & 302 & 82 & 199 & 13,1 & 166 & $-5,5$ \\
\hline Rusanov 1 & 457762 & 8893341 & 201 & 473 & 60 & 240 & 19,5 & 194 & $-3,3$ \\
\hline Rusanov 2 & 480060 & 8885389 & 80 & 136 & 50 & 82 & 2,7 & 79 & $-1,2$ \\
\hline Rusanov 3 & 472768 & 8864412 & 309 & 517 & 161 & 325 & 5,2 & 300 & $-2,6$ \\
\hline Rusanov 4 & 466164 & 8861665 & 157 & 320 & 63 & 156 & $-1,0$ & 160 & 1,6 \\
\hline University 1 & 511895 & 8783252 & 117 & 452 & 17 & 120 & 3,1 & 118 & 1,4 \\
\hline University 2 & 515118 & 8756727 & 134 & 219 & 34 & 142 & 6,2 & 130 & $-3,1$ \\
\hline Vavilov & 406736 & 8808844 & 2062 & 4586 & 424 & 2117 & 2,6 & 2021 & $-2,0$ \\
\hline
\end{tabular}


Table B4. Svalbard: statistics for time series of Sentinel-1 velocity 2015-2021.

\begin{tabular}{|c|c|c|c|c|c|c|c|c|c|}
\hline Name & Long. & Lat. & $\begin{array}{l}\text { Mean } \\
\text { Year }\end{array}$ & $\begin{array}{l}\text { Max } \\
\text { Year }\end{array}$ & $\begin{array}{l}\text { Min } \\
\text { Year }\end{array}$ & $\begin{array}{c}\text { Mean } \\
\text { Summer }\end{array}$ & $\begin{array}{l}\text { Percent } \\
\text { Summer }\end{array}$ & $\begin{array}{c}\text { Mean } \\
\text { Winter }\end{array}$ & $\begin{array}{l}\text { Percent } \\
\text { Winter }\end{array}$ \\
\hline Austre_Torellbreen & 502580 & 8565444 & 442 & 835 & 80 & 466 & 5.5 & 429 & -2.9 \\
\hline Basin 3 & 711428 & 8832955 & 2650 & 4110 & 1645 & 2787 & 5.2 & 2538 & -4.2 \\
\hline Bodleybreen & 627736 & 8868785 & 510 & 915 & 70 & 440 & -13.6 & 534 & 4.8 \\
\hline Borebreen & 478403 & 8706253 & 168 & 347 & 14 & 213 & 26.7 & 153 & -9.4 \\
\hline Dahlbreen & 444663 & 8725316 & 246 & 382 & 125 & 234 & -4.8 & 250 & 1.7 \\
\hline Davisbreen & 556124 & 8574936 & 192 & 410 & 31 & 220 & 14.5 & 178 & -7.0 \\
\hline Duvebreen & 667145 & 8913229 & 183 & 389 & 19 & 171 & -6.6 & 186 & 1.6 \\
\hline Fjortende_Julibreen & 436246 & 8784037 & 301 & 705 & 45 & 273 & -9.2 & 309 & 2.7 \\
\hline Frazerbreen & 606529 & 8862302 & 182 & 300 & 41 & 163 & -10.2 & 189 & 3.7 \\
\hline Hansbreen & 516088 & 8549357 & 202 & 1208 & 8 & 156 & -22.7 & 219 & 8.4 \\
\hline Hinlopenbreen & 583959 & 8784448 & 305 & 1109 & 3 & 447 & 46.2 & 266 & -12.8 \\
\hline Hornbreen & 542711 & 8553974 & 402 & 1246 & 105 & 461 & 14.5 & 377 & -6.3 \\
\hline Idabreen & 445555 & 8837424 & 199 & 501 & 30 & 133 & -33.1 & 227 & 14.2 \\
\hline Idunbreen & 592453 & 8858413 & 334 & 649 & 34 & 343 & 2.7 & 326 & -2.6 \\
\hline Kongsbreen & 450119 & 8766388 & 396 & 683 & 152 & 326 & -17.6 & 425 & 7.4 \\
\hline Konowbreen & 456867 & 8724324 & 258 & 459 & 36 & 241 & -6.9 & 265 & 2.6 \\
\hline Kronebreen & 448626 & 8756665 & 1042 & 1760 & 491 & 1165 & 11.8 & 1004 & -3.7 \\
\hline Leighbreen & 723112 & 8918854 & 653 & 1134 & 366 & 578 & -11.5 & 682 & 4.4 \\
\hline Lilliehöökbreen_W & 430572 & 8813106 & 446 & 705 & 179 & 389 & -12.7 & 465 & 4.3 \\
\hline Monacobreen & 449191 & 8827445 & 987 & 1905 & 80 & 950 & -3.7 & 994 & 0.7 \\
\hline Muehlbacherbreen & 522618 & 8558392 & 318 & 593 & 30 & 235 & -26.0 & 351 & 10.3 \\
\hline Negribreen & 590175 & 8725568 & 3148 & 8663 & 165 & 3668 & 16.5 & 2905 & -7.7 \\
\hline Olsokbreen & 537713 & 8515419 & 532 & 1340 & 29 & 638 & 19.9 & 502 & -5.6 \\
\hline Petermannbreen & 584480 & 8716920 & 546 & 1087 & 240 & 594 & 8.9 & 521 & -4.4 \\
\hline Rijpbreen & 626849 & 8899792 & 573 & 860 & 342 & 577 & 0.8 & 566 & -1.2 \\
\hline Schweigaardbreen & 686848 & 8923033 & 643 & 944 & 198 & 623 & -3.2 & 645 & 0.4 \\
\hline Seligerbreen & 446360 & 8828938 & 341 & 1061 & 122 & 276 & -19.1 & 369 & 8.3 \\
\hline Smeerenburgbreen & 431070 & 8840351 & 249 & 426 & 95 & 210 & -15.8 & 265 & 6.4 \\
\hline Svalisbreen & 543289 & 8546268 & 369 & 1217 & 53 & 337 & -8.7 & 380 & 3.0 \\
\hline Sveabreen & 483328 & 8718988 & 461 & 975 & 93 & 370 & -19.8 & 499 & 8.2 \\
\hline
\end{tabular}


Figure C1. Novaya Zemlya: time series of Sentinel-1 velocity 2015-2021.

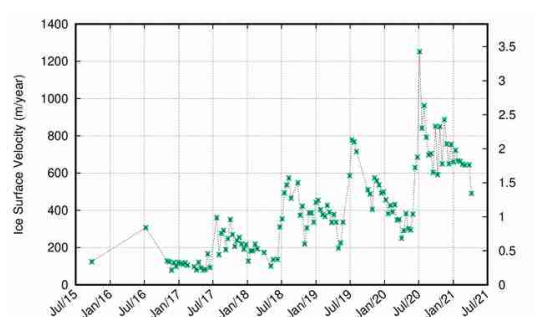

Severny_1

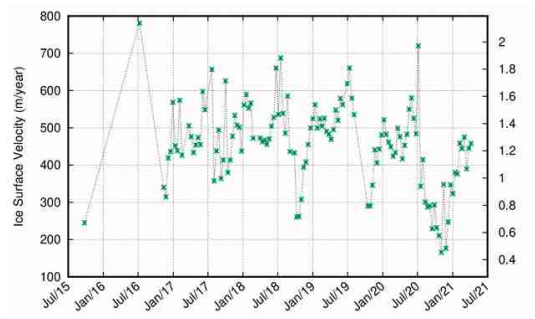

Vize_4

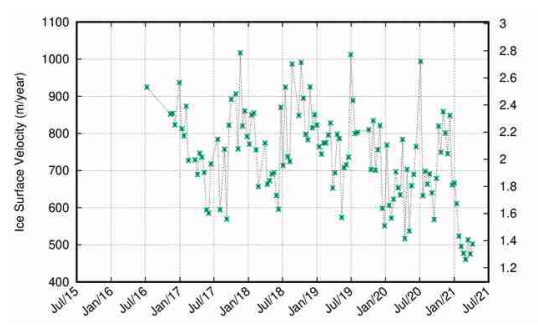

Severny_7

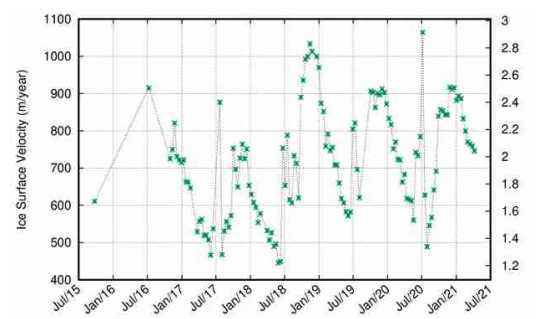

Shokalskiy_10

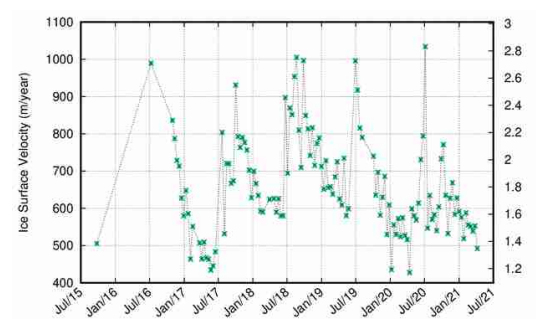

Severny_2

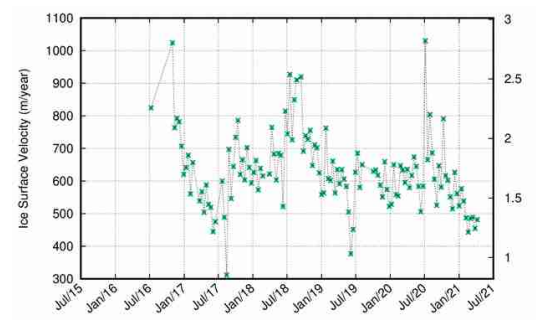

Severny 5

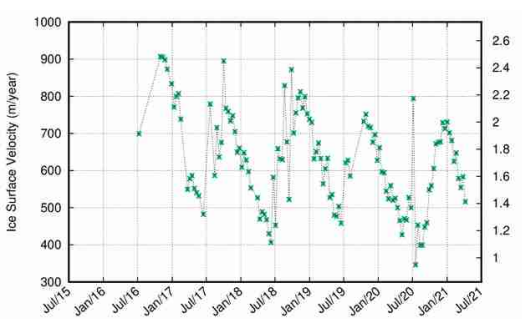

Severny_8

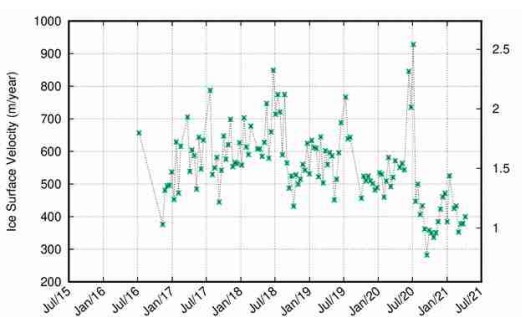

Chernyshev_11

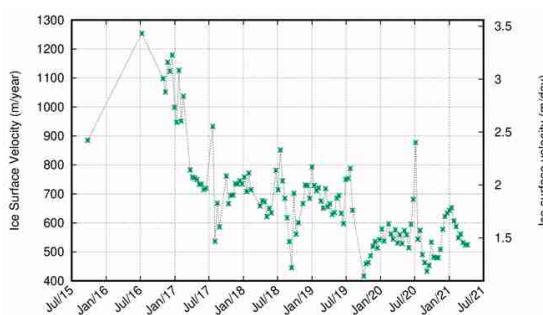

Severny_3

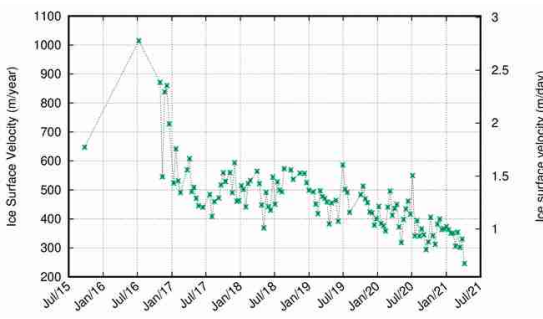

Severny_6

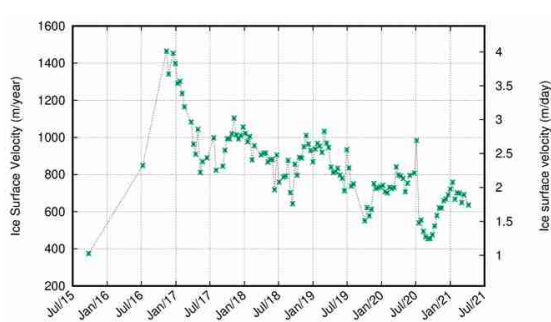

Severny_9

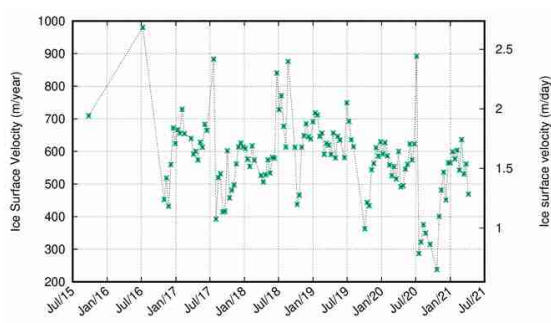

Krayniy_Popov_12 


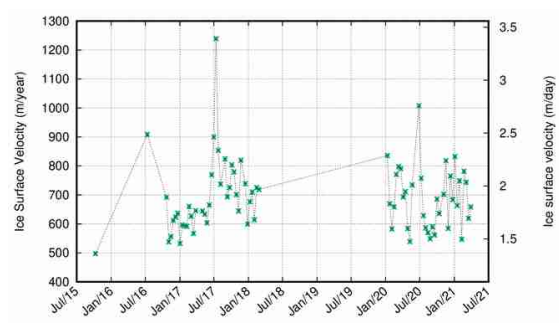

Krivosheina_13

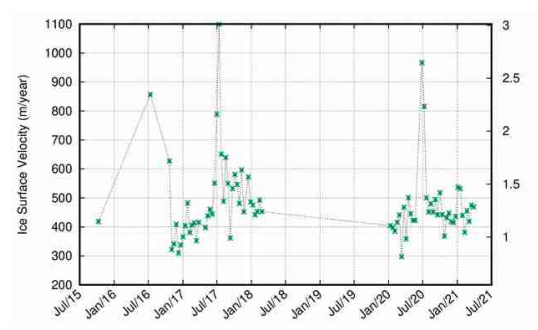

Nordenskiold_16

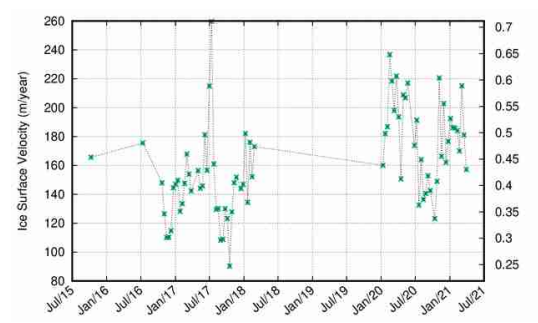

Severny_92

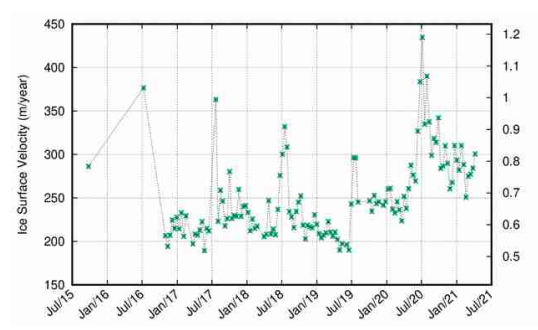

Vylki_Shury_95

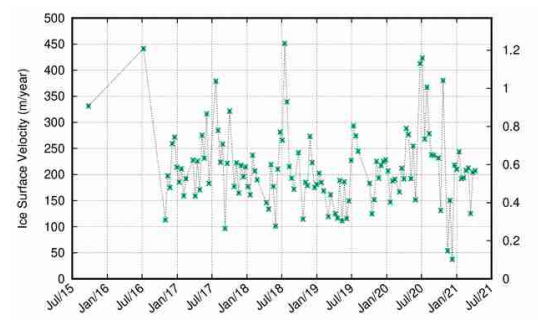

Severny_98

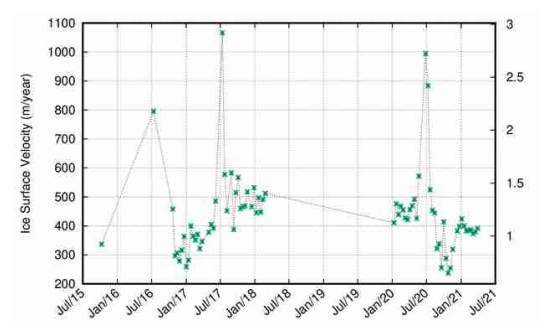

Vilkitskiy_14

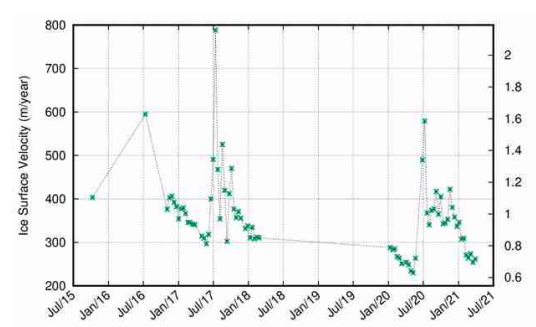

Glazov_17

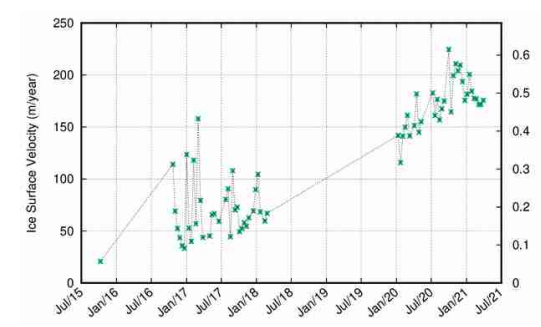

Severny_93

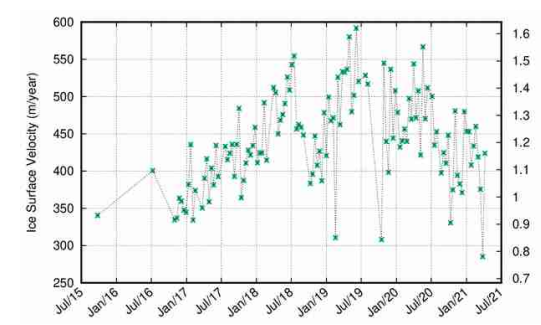

Severny_96

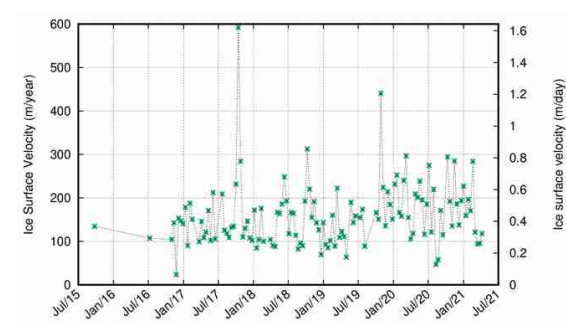

Severny_99

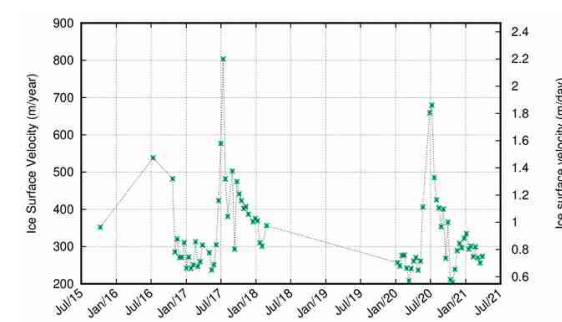

Severny_15

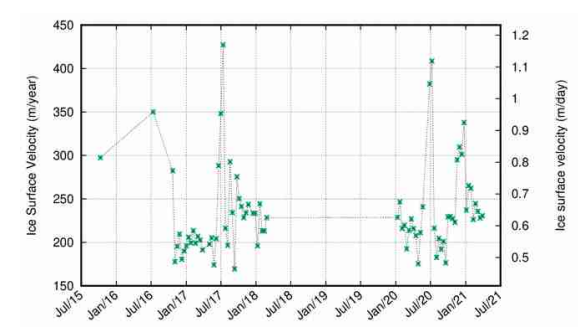

Nizkiy_18

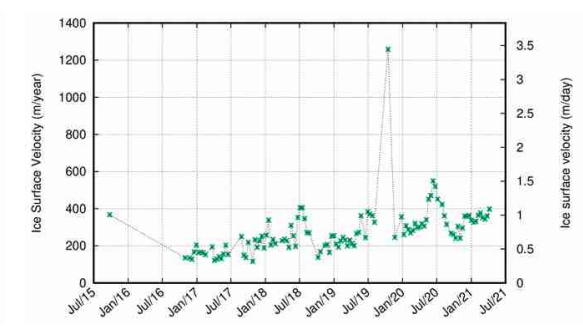

Severny_94

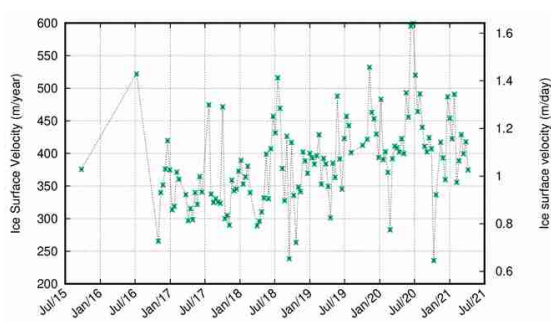

Moshchnyy_97 
Figure C2. Franz-Josef-Land: time series of Sentinel-1 velocity 2015-2021.

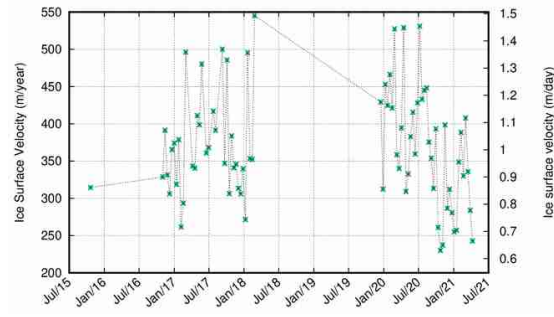

Brousilov_1

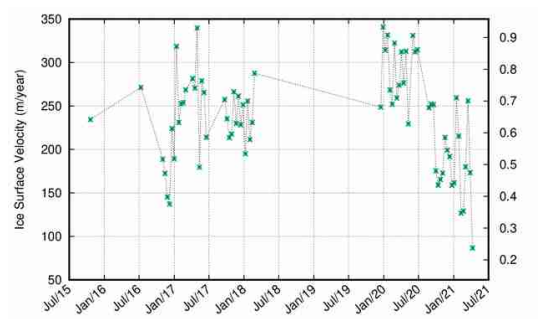

Brousilov_4

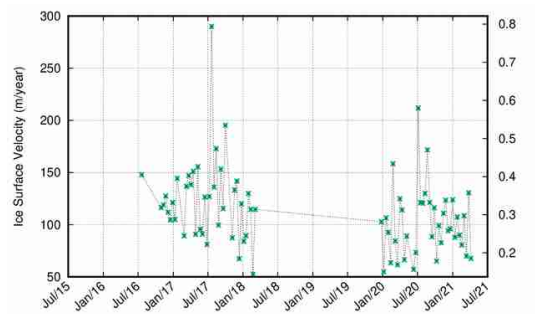

Forbes

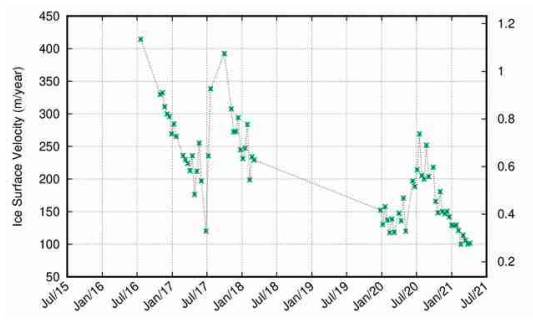

Moscow 1

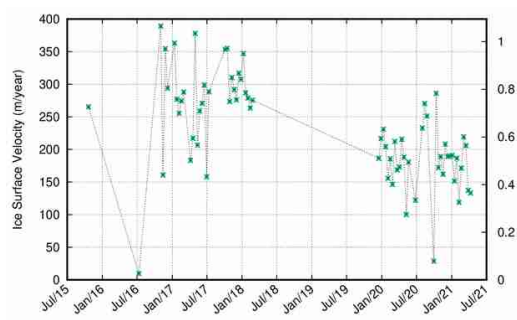

Northbrook_2

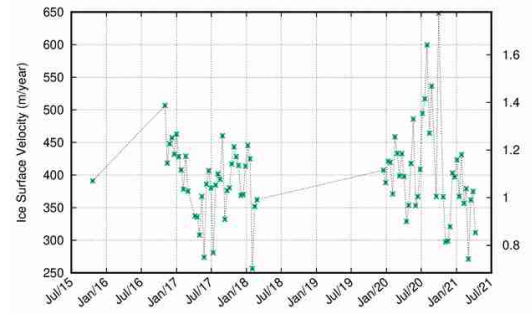

Brousilov 2

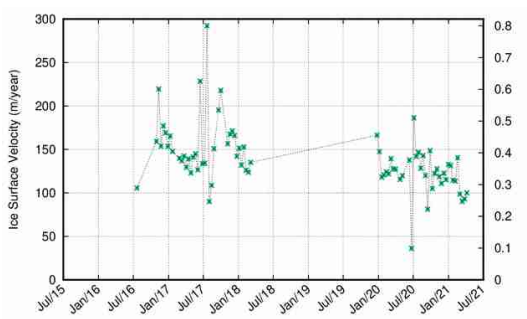

Champ

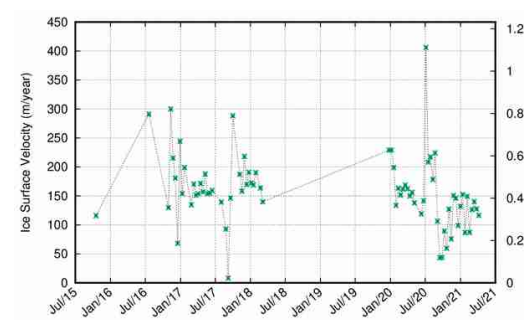

Luigi

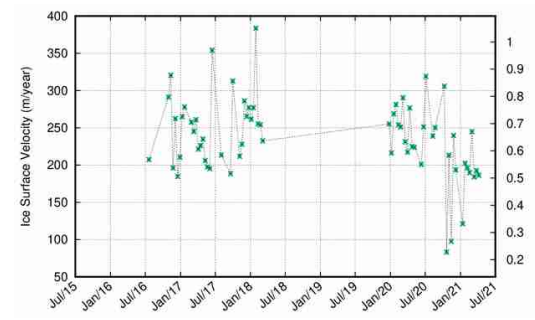

Moscow 2

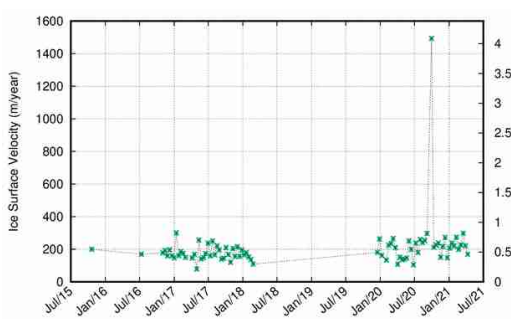

Rudolph_Island_1

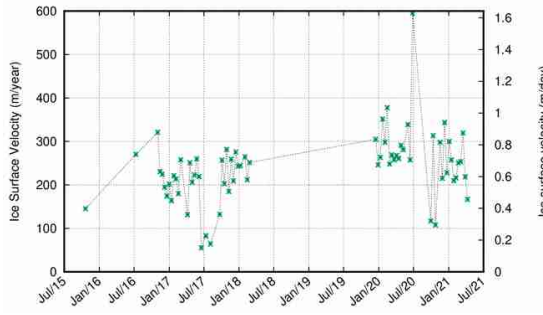

Brousilov 3

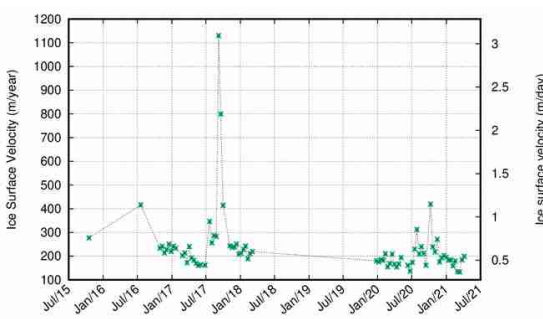

Chernysheva

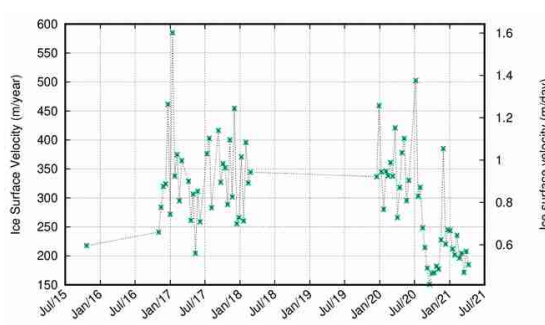

Moon_4

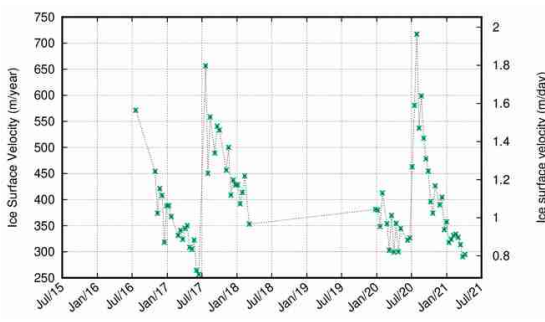

Moscow 3

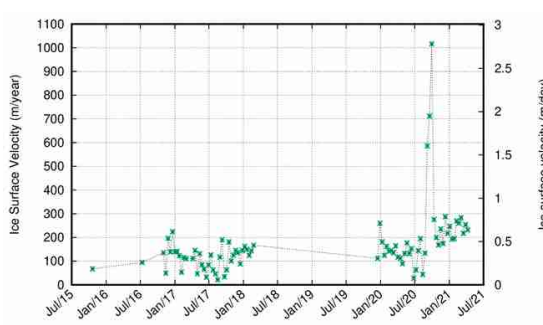

Rudolph_Island_2 


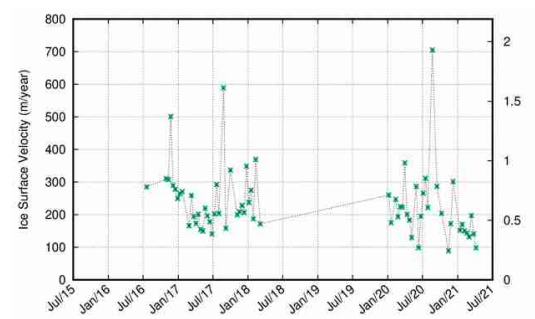

Salisbury_1

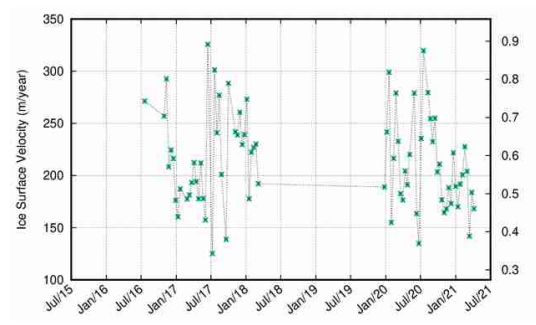

Simony_3

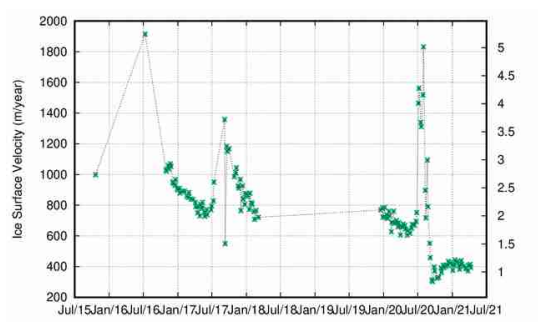

TyndallIceCap_4

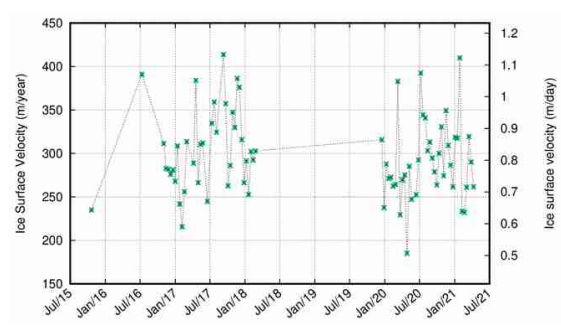

Vostok-1IceCap_1

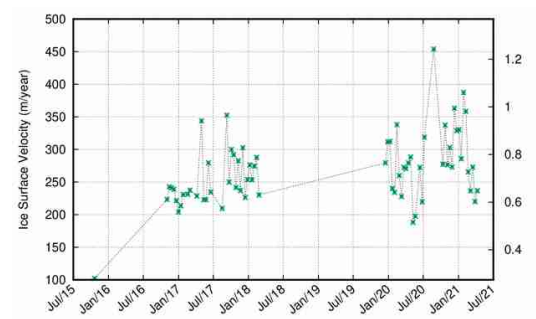

SamoylovitchIceCap_1

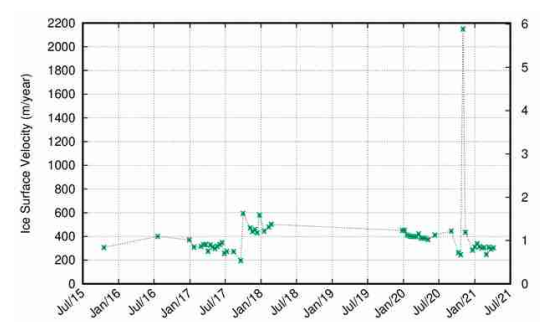

TyndallIceCap_2

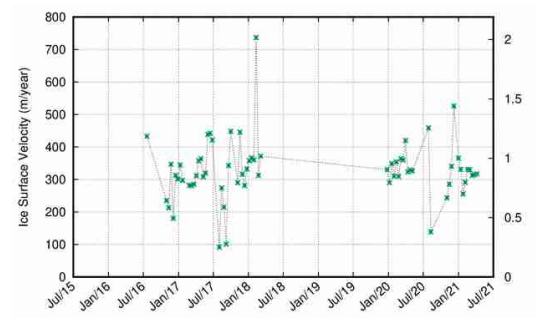

TyndallIceCap_6

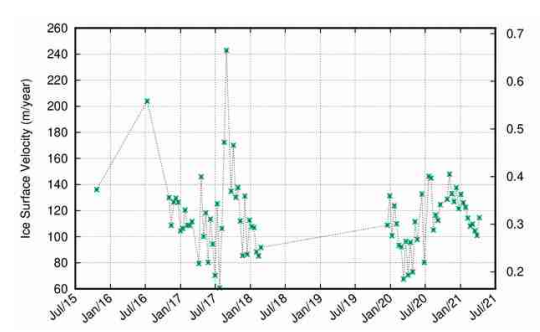

Vostok-1IceCap_2

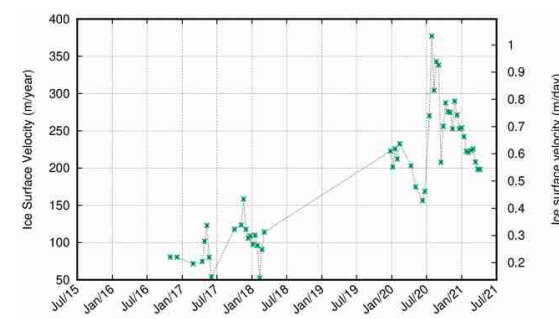

Simony_1

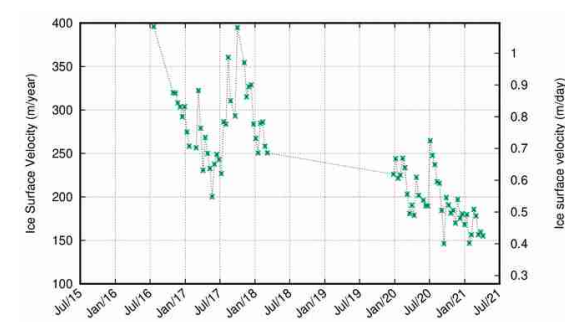

TyndallIceCap_3

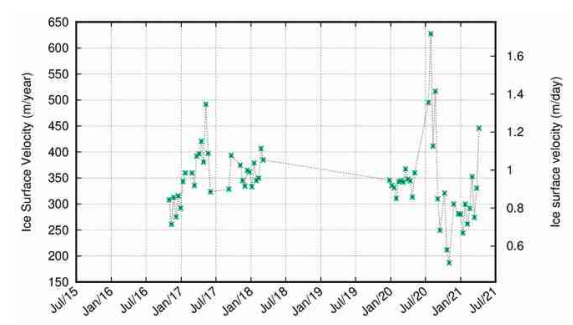

TyndallIceCap_7

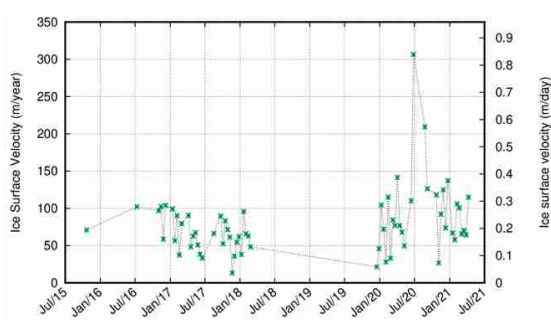

Vostok-1IceCap_3 
Figure C3. Severnaya Zemlya: time series of Sentinel-1 velocity 2015-2021.

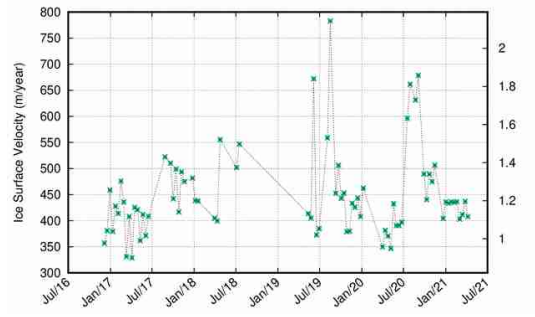

Academy_of_Sciences_1

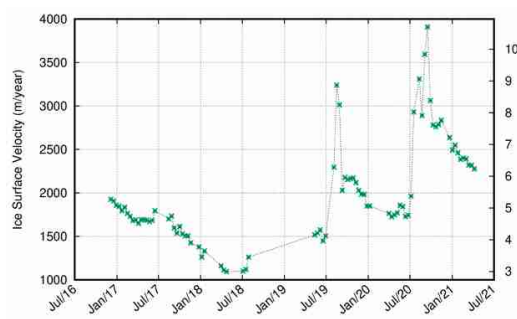

Academy_of_Sciences_4

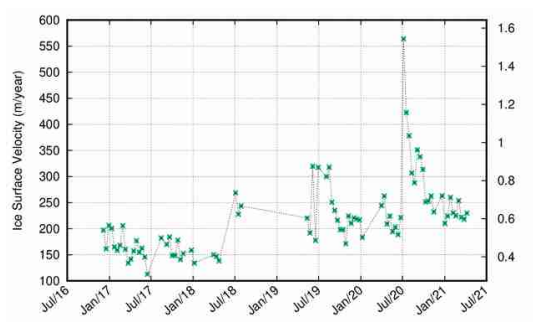

Academy_of_Sciences_7

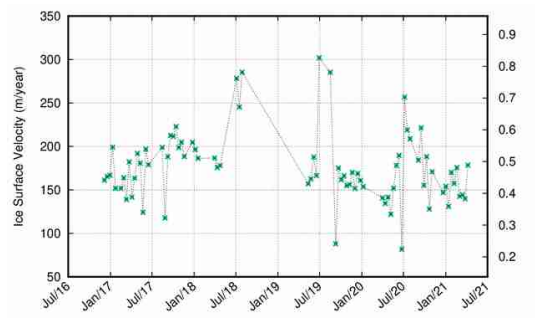

Karpinsky_Ice_Cap_3

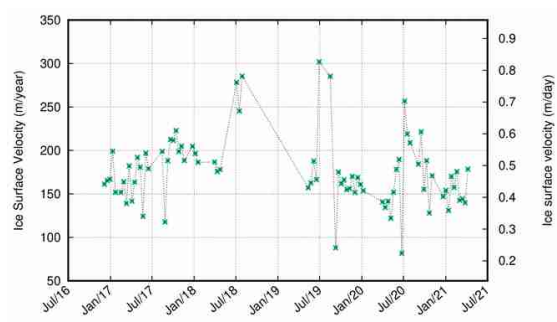

Rusanov_Ice_Cap_3

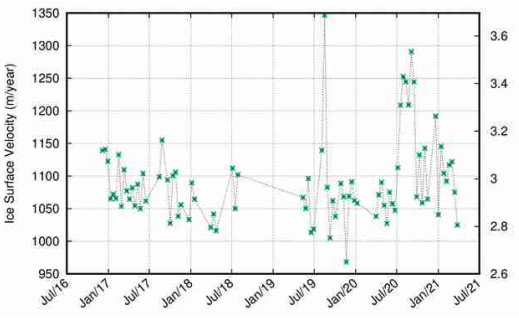

Academy_of_Sciences_2

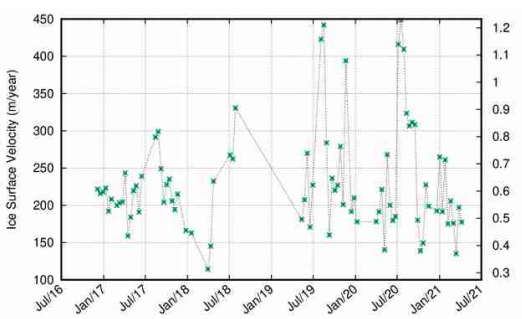

Academy_of_Sciences_5

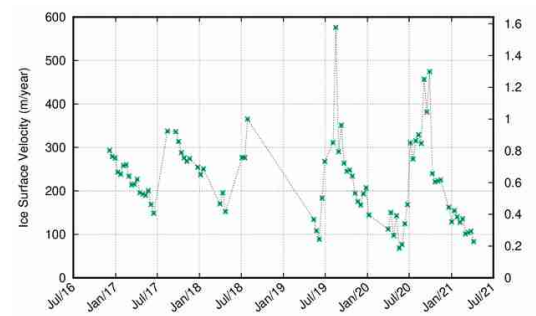

Karpinsky_Ice_Cap_1

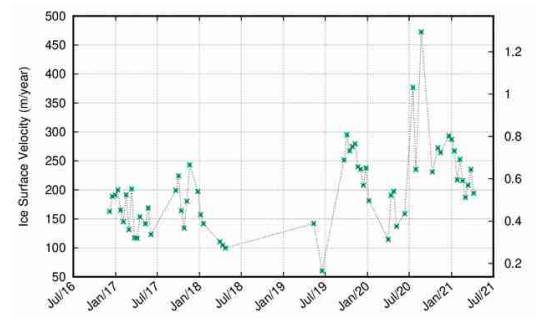

Rusanov_Ice_Cap_1

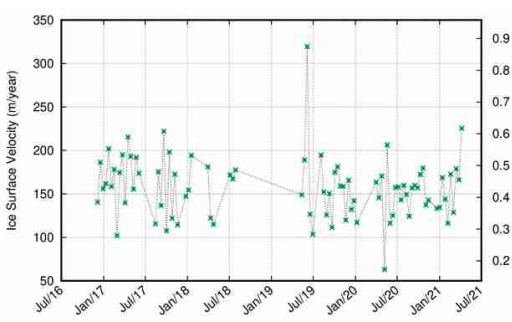

Rusanov_Ice_Cap_4

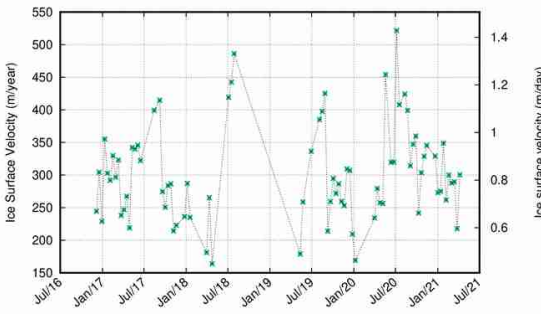

Academy_of_Sciences_3

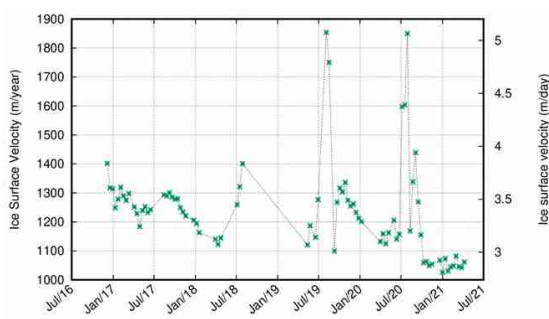

Academy_of_Sciences_6

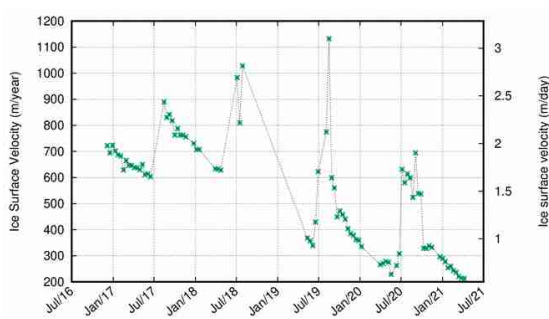

Karpinsky_Ice_Cap_2

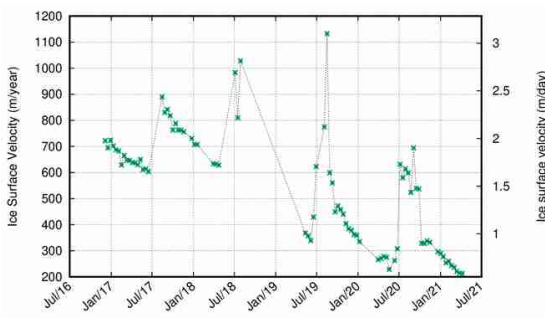

Rusanov_Ice_Cap_2

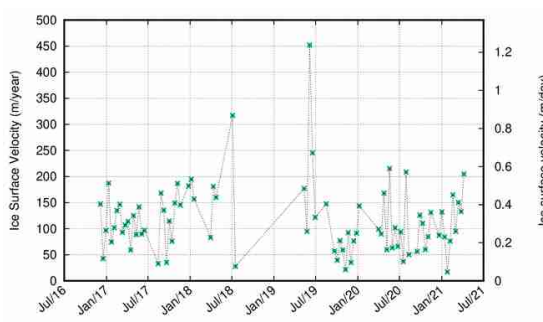

University_Ice_Cap_1 


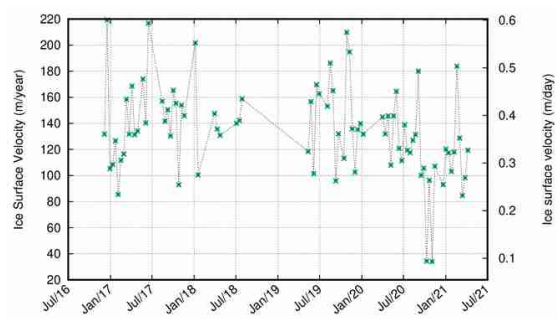

University_Ice_Cap_2

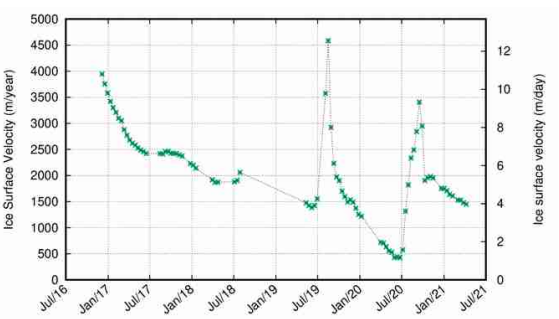

Vavilov_T77 
Figure C4. Svalbard: time series of Sentinel-1 velocity 2015-2021.

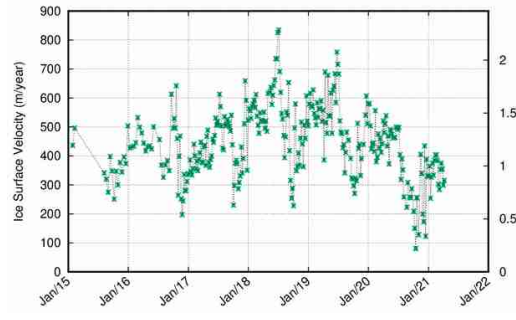

Austre Torellbreen

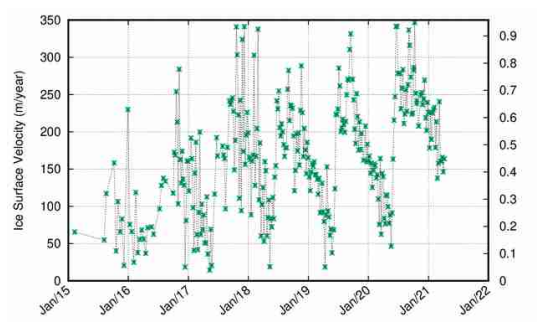

Borebreen

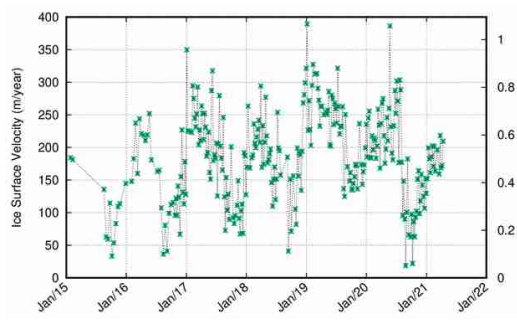

Duvebreen

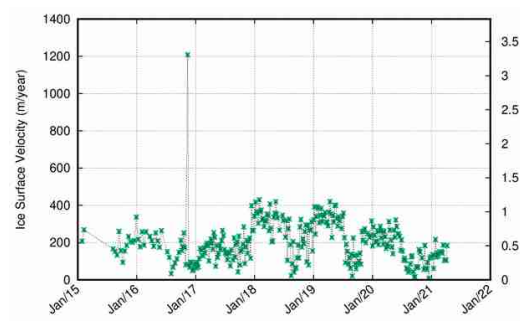

Hansbreen

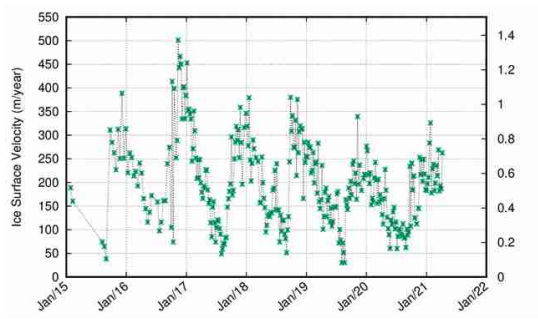

Idabreen

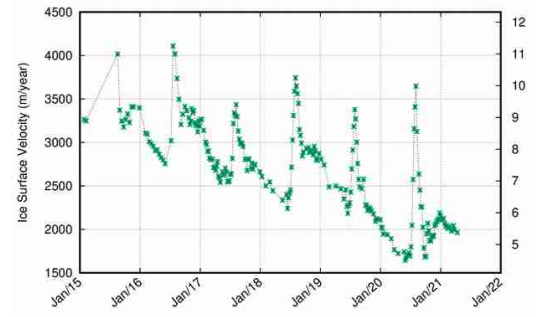

Basin 3

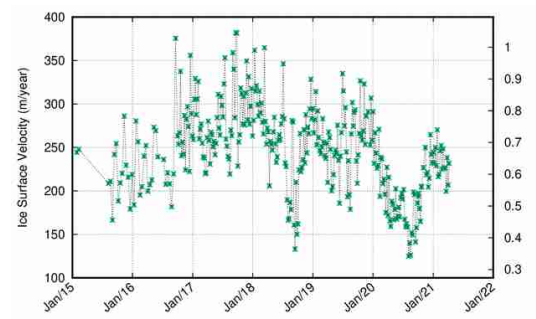

Dahlbreen

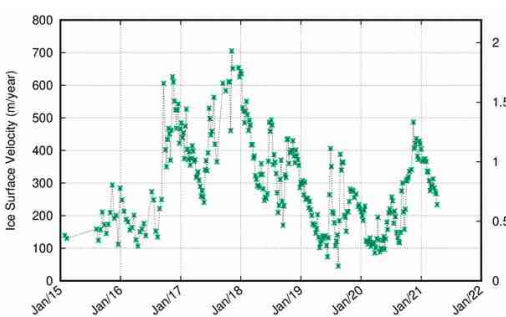

Fjortende Julibreen

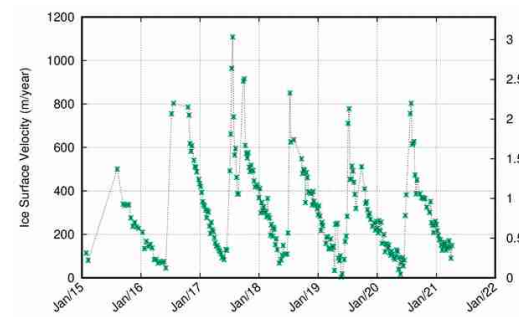

Hinlopenbreen

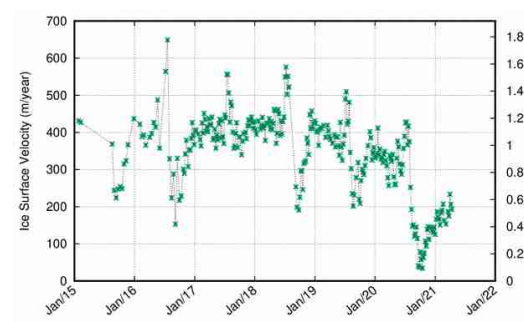

Idunbreen

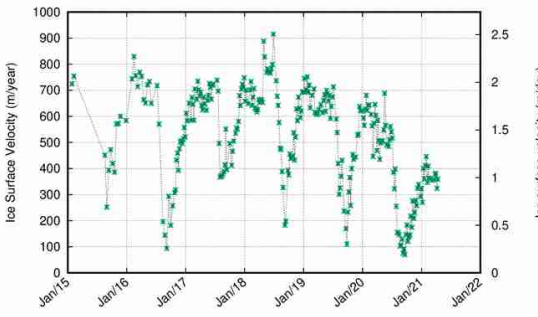

Bodleybreen

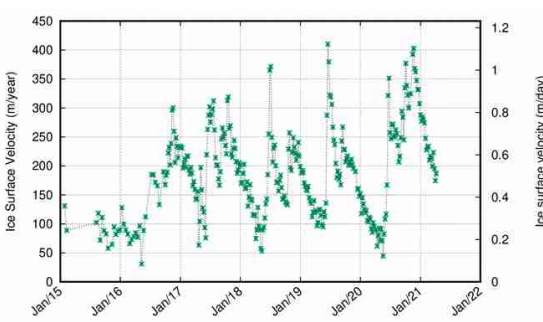

Davisbreen

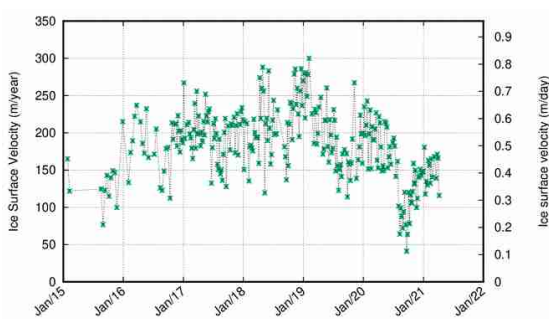

Frazerbreen

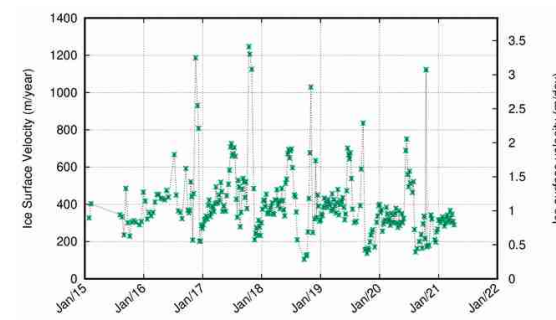

Hornbreen

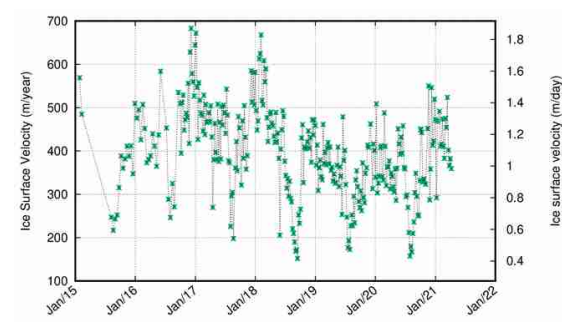

Kongsbreen 


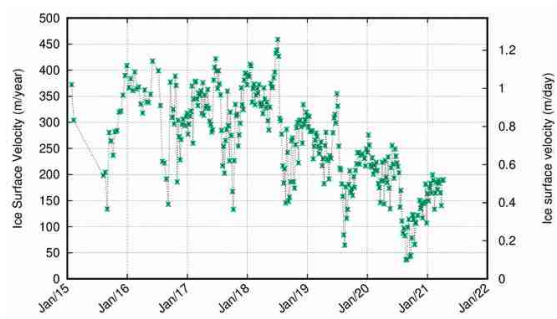

Konowbreen

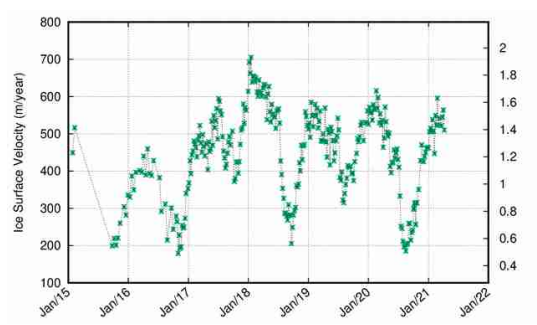

Lilliehöökbreen West

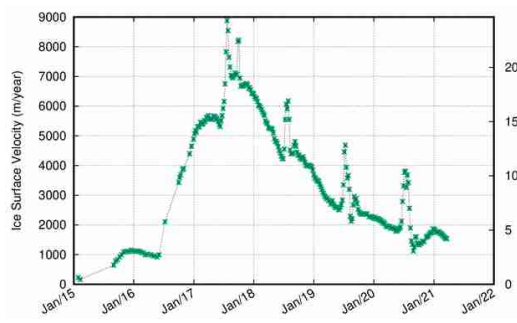

Negribreen

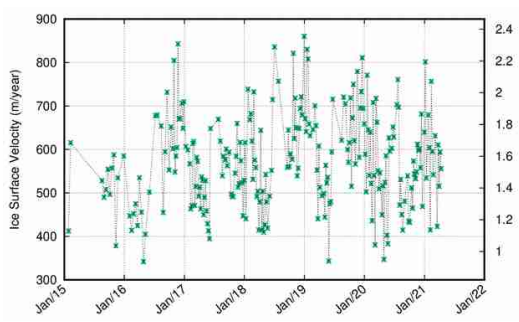

Rijpbreen

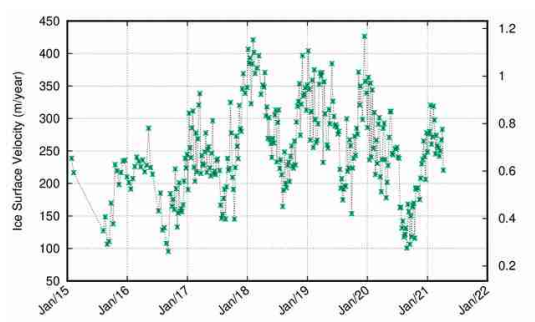

Smeerenburgbreen

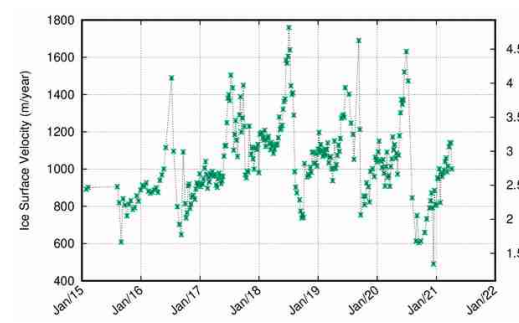

Kronebreen

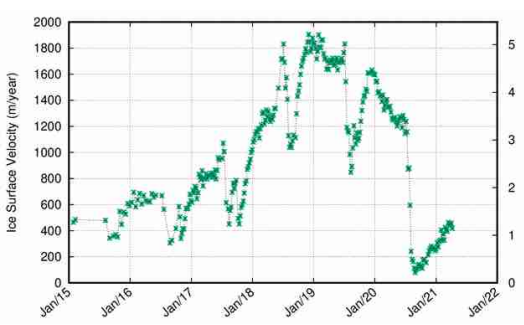

Monacobreen

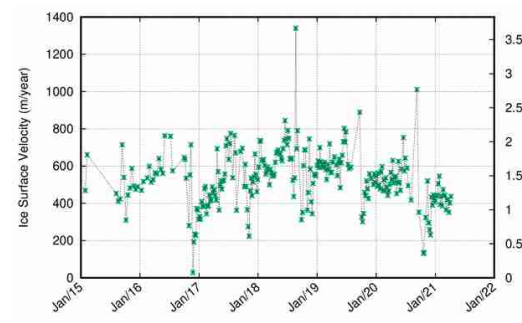

Olsokbreen

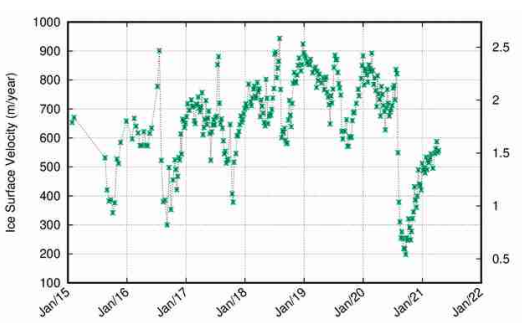

Schweigaardbreen

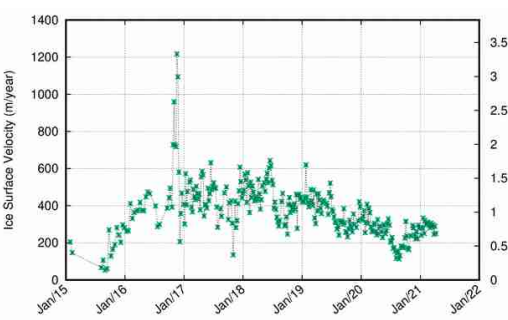

Svalisbreen

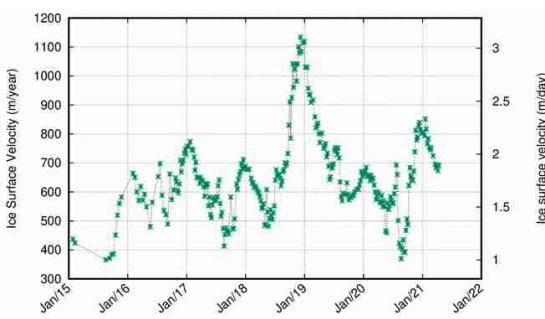

Leighbreen

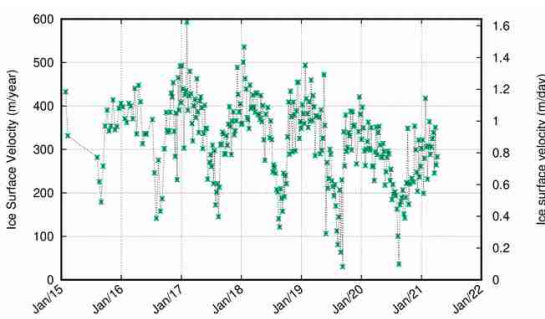

Muehlbacherbreen

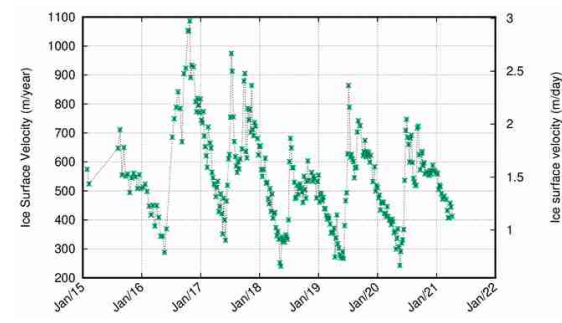

Petermannbreen

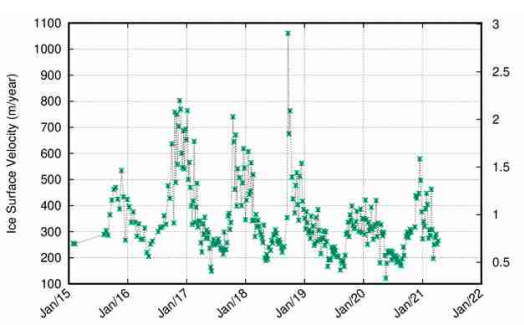

Seligerbreen

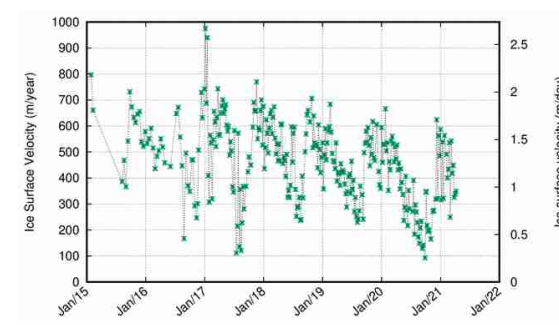

Sveabreen 